\title{
Paracetamol (Acetaminophen) Use in Infants and Children Was Never Shown to Be Safe for Neurodevelopment: A Systematic Review
}

\author{
Jasmine Cendejas-Hernandez
}

Duke University Medical Center

Joshua Sarafian

Duke University Medical Center

\section{Victoria Lawton}

Duke University Medical Center

\section{Antara Palkar}

Duke University Medical Center

\section{Lauren Anderson}

Duke University Medical Center

\section{Vincent Lariviere}

University of Montreal

William Parker ( $\sim$ William.Parker@Duke.edu )

Duke University Medical Center Library: Duke University School of Medicine https://orcid.org/00000003-3644-9152

\section{Research}

Keywords: behavior, neurodevelopment, infant, child, autism

Posted Date: November 18th, 2020

DOl: https://doi.org/10.21203/rs.3.rs-107410/v1

License: (a) (1) This work is licensed under a Creative Commons Attribution 4.0 International License. Read Full License 


\section{Abstract}

Background: Although widely believed to be safe for use in infants and children when used as directed, increasing evidence indicates that early life exposure to paracetamol (acetaminophen) may cause longterm neurodevelopmental problems. Further, recent studies in animal models demonstrate that cognitive development is exquisitely sensitive to paracetamol exposure during early development. In this study, evidence for the claim that paracetamol is safe was evaluated using a systematic literature search.

Methods: Publications on PubMed between 1974 and 2017 that contained the keywords "infant" and either "paracetamol" or "acetaminophen" were considered. Of those initial 3096 papers, 218 were identified that made claims that paracetamol was safe for use with infants or children. Of these, a total of 103 papers were identified as sources of authority for the safety claim, and 36 of those contained actual experiments designed to test safety.

Results and Conclusions: The 36 experiments described had a median follow-up time of 24 hours, and none monitored neurodevelopment. Further, no trial considered total exposure to drug since birth, eliminating the possibility that the effects of drug exposure on long-term neurodevelopment could be accurately assessed. On the other hand, abundant and sufficient evidence was found to conclude that paracetamol does not induce acute liver damage in babies or children when used as directed.

\section{Background}

Hundreds of reports claim emphatically that, when used as directed, paracetamol (acetaminophen) is safe for use in babies and in children. However, mounting evidence points toward the view that paracetamol exposure during early development can have an adverse effect on neurodevelopment, even when used as directed. For example, in a recent review [1], eight studies supporting a link between prenatal paracetamol exposure and neurodevelopmental problems were identified [2-9]. In the three years since that review, five additional studies have confirmed this same relationship, three of which have used data from the Norwegian Mother and Child Cohort Study [10-14]. Although exposure to paracetamol in utero is associated with neurodevelopmental problems, even after consideration of potentially confounding factors, the effects are typically small and the amount of paracetamol required to yield the effect is greater than the amount typically used by average individuals. For example, after adjusting for potential confounders such as parental education level, use of vitamin supplements, parental BMI, smoking, and use of other drugs, Skovlund and colleagues found a weak yet significant association between prenatal exposure to paracetamol and mother-reported communication skills: the chances of being in a lower development category increased with increasing periods of prenatal paracetamol use but not prenatal opioid use [10]. In another example, using propensity score matching, Vlenterie and colleagues found that 28 or more days of paracetamol use during pregnancy was associated with a modestly increased risk of delayed motor milestone attainment (OR: $1.35,95 \% \mathrm{Cl} 1.07-$ 1.70) by children at 18 months [11]. 
Evidence points toward a higher risk of paracetamol-induced neurodevelopmental disorders when exposure occurs after birth as compared to in utero. Studies using laboratory rodents demonstrate that exposure to near therapeutic doses of paracetamol during the first days of life induces profound, longterm neurological changes $[15,16]$, whereas somewhat higher doses are required to induce permanent neurological damage during pregnancy [17]. These laboratory studies demonstrate that the target organ for toxicity in neonates is the central nervous system, not the liver, and demonstrate that if paracetamol had been tested using current guidelines, it would never have been approved for use in children. More concerning are observations in children indicating that paracetamol is not safe for neurodevelopment. The 2008 study which first raised a red flag regarding the safety of paracetamol during neurodevelopment found a greater than 20 -fold risk of regressive autism with paracetamol use during childhood [18]. Although this relatively small study did not attract enough interest to promote larger studies, other lines of evidence support the view that paracetamol exposure during early life can lead to neurodevelopmental disorders. For example, a startling 2-fold greater incidence of infantile autism in circumcised boys compared to non-circumcised boys [19] can be readily explained by potentially negative impacts of paracetamol exposure during and following the circumcision procedure [1]. Sadly, the widely held and entrenched belief that vaccines induce autism $[20,21]$ may be yet another result of the impact of paracetamol on neurodevelopment in combination with widespread use of the drug during vaccination [1].

With the above concerns in mind, a systematic evaluation of the peer-reviewed literature was initiated to address the question of why paracetamol is widely believed to be safe for use during early development. All papers published between 1974 and 2017 that contained the keywords "infant" and either "paracetamol" or "acetaminophen" were considered. All papers which made claims that paracetamol or acetaminophen is safe for use in infants or children were identified, and the justification for this claim was critically evaluated.

\section{Methods}

As a first step in understanding why paracetamol is thought to be safe during early development, all titles and abstracts in the PubMed $\circledast$ Database with keywords "infant" and "acetaminophen or paracetamol" published between 1974 and 2017 were identified. The term "infant" rather than "child" was selected because (a) the number of papers with the term "child" was prohibitively large, and (b) the focus of the study was intended to be on drug exposure during early development, from birth to age approximately 6 years, not individuals up to the age of 17 years. In all cases, the terms paracetamol and acetaminophen were taken to be synonymous, and no distinctions were made.

In the second step, two coauthors (JCH and JTS) independently screened all titles and abstracts. In this step, articles that could not be obtained in English and all articles not describing use of paracetamol in humans were eliminated from the study. Based on titles and abstracts (if available), articles were tagged which were deemed likely to make claims regarding the safety of acetaminophen use in infants and children between birth and age 6 years. 
In the third step, two coauthors (JCH and JTS), continuing to work independently, examined full texts of all tagged titles and abstracts. Texts were examined for the following three assertions:

(a) paracetamol use is "safe" in children or infants

(b) paracetamol is the "drug of choice" in children or infants

(c) paracetamol use is "recommended" for children or infants

In cases where the terms "drug of choice" or "recommended" were used, the context was considered. In some cases, particularly in manuscripts expressing caution regarding the use of paracetamol, these terms were not taken to imply safety, but rather were taken to be an indicator of the common acceptance of the drug. These articles were excluded from the study. Based on this approach, articles were tagged that were considered to have made safely claims regarding the use of paracetamol in infants or children younger than 6 years old.

Still working independently, two coauthors (JCH and JTS) evaluated each manuscript making a claim of safety, determining the source of authority for the stated claim. If no literature was cited to support the claim, this was documented. In cases where the source that was cited contained another citation, that secondary reference was obtained and evaluated. This process continued as needed until an original source or sources describing an actual demonstration of safety was identified. An example of the results of this process is shown in Fig. 1.

Table 1

Number of citations identified in the systematic search during each step of the study. Numbers are provided for both analysts performing the work (JCH and JTS). The overlap is the number of citations that were the same between the two analysts. *Numbers in parentheses indicated the number of citations in which both analysts identified the same citation, but not the same source or sources as the authority for claims of safety.

\begin{tabular}{|lllll|}
\hline Step & JCH & Overlap & JTS & Total \\
\hline 1. Medline (paracetamol + infant) & & & 3096 \\
\hline 2. Safety claim, first step & 310 & 193 & 350 & 467 \\
\hline 3. Safety claim, second step & 189 & $144\left(53^{\star}\right)$ & 189 & 234 \\
\hline 4. Safety claim, final & 173 & $128\left(37^{\star}\right)$ & 173 & 218 \\
\hline 5. Sources attributed to safety claim & & & & 103 \\
\hline 6. Sources with experiments attributed to safety claim & & & 36 \\
\hline
\end{tabular}


Table 2

Sources cited as stating that acetaminophen is safe for infants or children when used as directed. *This article is cited as "Renn E. The antipyretic use of paracetamol versus ibuprofen in a pediatric care setting.

Physical Therapy. 2000;25:395-397." This reference does not apparently exist: The volume number corresponding to the year 2000 for the journal Physical Therapy is 80 , not 25 . We were unable to determine what actual article it may have originally referred to. $* \star$ The Canadian Pediatric Society paper

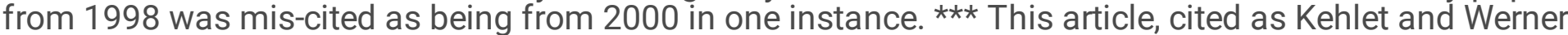
(2003) from the journal Drugs, Volume 63, pp 15-22 (Spec no 2), does not exist on the journal's website for unknown reasons.

\section{Sources cited for safety of paracetamol in children or infants: study number, year, and design}

1. 1999: Double-blind clinical trial with three treatments, one of paracetamol and two different concentrations of ibuprofen given for fever [22]

\section{1997: Double-blind,} randomized, three-way crossover study with three treatments, one each of paracetamol, ibuprofen, and placebo given by parents for headache. Each child with three migraine attacks was treated in random order with single oral doses of the study drugs [34]

\section{Study subjects}

9,127 children treated with paracetamol; median age is 14 months

\section{for unknown reasons.}




\begin{tabular}{|c|c|c|c|c|}
\hline $\begin{array}{l}\text { Sources cited for } \\
\text { safety of paracetamol } \\
\text { in children or infants: } \\
\text { study number, year, } \\
\text { and design }\end{array}$ & Study subjects & $\begin{array}{l}\text { Outcome measures } \\
\text { related to safety or } \\
\text { safety claims made. }\end{array}$ & $\begin{array}{l}\text { Duration of } \\
\text { monitoring }\end{array}$ & $\begin{array}{l}\text { Times } \\
\text { cited }\end{array}$ \\
\hline
\end{tabular}

5. 1978: Review describing antipyretic therapy in febrile children [37]
NA: Review

NA: Review
Claims: "relatively free of adverse reactions" without citation and 9 citations provided for the statement that hepatotoxicity from paracetamol in children is "very low compared with that seen in adults"

6. 2000: Renn, 2000

Erroneous citation* NA: Erroneous NA: Erroneous citation citation

$$
\text { NA: Report }
$$

7. 2011: Report describing current recommended practice [38]

Claims: "generally

regarded as safe"

without citation. Lesko

(1999) is cited for

NA: Review

NA: Erroneous citation

7

NA: Report

7

equivalent safety

between ibuprofen and

paracetamol.

NA: Review

Claims: "one of the

safest" without citation

NA: Review

6

describing pediatric

dosing of

paracetamol [39]

9. 1995: Double-blind

clinical trial with three

treatments, one of

paracetamol and two

of different

concentrations

ibuprofen given for

fever [40]

10. 1998: Practice

guidelines** [41]
28,130 children treated with paracetamol; median age is 40 months
Serious events defined as hospitalization for acute gastrointestinal bleeding, acute renal failure, or anaphylaxis.
4 weeks

6
NA: Practice
guidelines
Claims: "As

demonstrated by the numerous prospective clinical studies", paracetamol is "remarkably safe in therapeutic doses", without citation.
11. 1972: Double-blind study with two treatments, one each of aspirin and paracetamol, given for antipyretic effect [29]
39 children treated with paracetamol, age 6 months to 6 years
NA: Practice guidelines
Unspecified
"complications or side effects"

6 hours

5 


\begin{tabular}{|c|c|c|c|c|}
\hline $\begin{array}{l}\text { Sources cited for } \\
\text { safety of paracetamol } \\
\text { in children or infants: } \\
\text { study number, year, } \\
\text { and design }\end{array}$ & Study subjects & $\begin{array}{l}\text { Outcome measures } \\
\text { related to safety or } \\
\text { safety claims made. }\end{array}$ & $\begin{array}{l}\text { Duration of } \\
\text { monitoring }\end{array}$ & $\begin{array}{l}\text { Times } \\
\text { cited }\end{array}$ \\
\hline $\begin{array}{l}\text { 12. 1977: Clinical } \\
\text { guidelines for use, } \\
\text { predominantly } \\
\text { focused on aspirin, } \\
\text { but also including } \\
\text { paracetamol. [28] }\end{array}$ & $\begin{array}{l}\text { NA: Clinical } \\
\text { guidelines }\end{array}$ & $\begin{array}{l}\text { Considered to have a } \\
\text { "wide range of safety" } \\
\text { based on "the large } \\
\text { doses of paracetamol } \\
\text { required to evoke toxic } \\
\text { reactions" in laboratory } \\
\text { animals. In addition, } \\
\text { considered "safe and } \\
\text { effective when used as } \\
\text { directed", with two } \\
\text { studies cited }[29,30]\end{array}$ & $\begin{array}{l}\text { NA: Clinical } \\
\text { guidelines }\end{array}$ & 4 \\
\hline $\begin{array}{l}\text { 13. 1978: } \\
\text { Commentary on } \\
\text { paracetamol use [42] }\end{array}$ & $\begin{array}{l}\text { NA: } \\
\text { Commentary }\end{array}$ & $\begin{array}{l}\text { Claims: "safe and } \\
\text { effective analgesic and } \\
\text { antipyretic in usual } \\
\text { therapeutic dosage" } \\
\text { without citation. }\end{array}$ & $\begin{array}{l}\text { NA: } \\
\text { Commentary }\end{array}$ & 4 \\
\hline $\begin{array}{l}\text { 14. 1978: Review } \\
\text { comparing aspirin's } \\
\text { and paracetamol's } \\
\text { antipyretic and } \\
\text { analgesic activity [43] }\end{array}$ & NA: Review & $\begin{array}{l}\text { Claims: "the choice of } \\
\text { agents for antipyresis in } \\
\text { clinical practice has been } \\
\text { narrowed to aspirin and } \\
\text { paracetamol" without } \\
\text { citation. }\end{array}$ & NA: Review & 4 \\
\hline $\begin{array}{l}\text { 15. 1996: Review of } \\
\text { paracetamol liver } \\
\text { toxicity in children } \\
\text { under the age of } \\
6 \text { years [44] }\end{array}$ & NA: Review & $\begin{array}{l}\text { Makes no general safety } \\
\text { claim, although extensive } \\
\text { references are provided } \\
\text { showing that } \\
\text { paracetamol does not } \\
\text { cause long-term } \\
\text { damages to infants' } \\
\text { livers. }\end{array}$ & NA: Review & 4 \\
\hline $\begin{array}{l}\text { 16. 1997: Double-blind } \\
\text { clinical trial with three } \\
\text { treatments, one of } \\
\text { paracetamol and two } \\
\text { different } \\
\text { concentrations of } \\
\text { ibuprofen given for } \\
\text { fever [45] }\end{array}$ & $\begin{array}{l}97 \text { children } \\
\text { treated with } \\
\text { paracetamol; } \\
\text { median age is } \\
29 \text { months }\end{array}$ & $\begin{array}{l}\text { Renal function as } \\
\text { indicated by blood urea } \\
\text { nitrogen (BUN) and } \\
\text { creatinine levels. }\end{array}$ & 4 weeks & 4 \\
\hline $\begin{array}{l}\text { 17. 1972: Clinical } \\
\text { study with three } \\
\text { treatments, one each } \\
\text { of aspirin, } \\
\text { paracetamol, and a } \\
\text { combination of the } \\
\text { two given for fever } \\
\text { [30] }\end{array}$ & $\begin{array}{l}80 \text { children } \\
\text { treated with } \\
\text { paracetamol, } \\
\text { age } 6 \text { months to } \\
5 \text { years }\end{array}$ & $\begin{array}{l}\text { No outcome measures } \\
\text { specified. }\end{array}$ & 6 hours or less & 4 \\
\hline
\end{tabular}




\section{Sources cited for safety of paracetamol in children or infants: study number, year, and design}

18. 2005:

Pharmacokinetic study.
Study subjects

NA:

Pharmacokinetic study
No safety outcomes reported. No safety claims made.
Duration of monitoring
Times cited
[46]
19. 2011: Randomized open-label study with two dosing regimens of intravenous paracetamol given for analgesic or antipyretic effect.

[47] Intravenous paracetamol contains cysteine, an antidote for paracetamol poisoning. The antidote is not present in the oral medication.
75 patients total were treated with paracetamol, 3 neonates, 25 infants, 25 children, and 22 adolescents related to safety or safety claims made.
NA:

Pharmacokinetic study enzymes, changes in vital signs, and reported or observed adverse drug effects, which included the following: anemia, constipation, nausea, vomiting, face edema, pyrexia, hypokalemia, hypomagnesemia, hypophosphatemia, agitation, atelectasis, pleural effusion, pulmonary edema, stridor, wheezing, periorbital edema, and pruritus

NA: Review

20. 1973: Review describing precautions with paracetamol use
Makes no safety claim with respect to pediatric use.
NA: Review

[48]
21. 1981: Review comparing efficacy of aspirin and paracetamol in fever reduction in children
NA: Review
Claims: a "high degree of safety" at therapeutic doses without citation.

[49]

22. 1992:

Pharmacokinetic study in adults aged 21-25 years [50]
NA:

Pharmacokinetic study
NA: study in adults

NA:

Pharmacokinetic study

\section{1993: Review [51] NA: Review}

Claims: "Recent data have supported the relative safety (and efficiency) of paracetamol in newborn infants" without citation.
NA: Review 


\section{Sources cited for safety of paracetamol in children or infants: study number, year, and design}

24. 1996: Double-blind study with two treatments, one of each ibuprofen and paracetamol, given for fever [52]

25. 1997: Computer simulation used to predict dosing needed to achieve desired concentration of drug in plasma [53]

\section{Study subjects}

47 children were treated with paracetamol, age 0.2 to 9.4 years; median age is 1.6 years

NA: Computer simulation

\section{Outcome measures related to safety or safety claims made.}

Duration of monitoring
Times cited

$\begin{array}{lll}\text { 26. 1997: } & \text { NA: } & \begin{array}{l}\text { No safety outcomes } \\ \text { Pharmacokinetic }\end{array} \\ \text { study. } & \text { Pharmacokinetic } & \text { reported. } \\ \text { study. } & \begin{array}{l}\text { Claims: "Commonly used } \\ \text { in children because of its } \\ \text { (efficacy and) safety" } \\ \text { without citation. }\end{array}\end{array}$

27. 1999:

Pharmacokinetic study with a single rectal dose of paracetamol [55]

28. 2007: Comparison of efficacy between paracetamol and ibuprofen. First phase was a single dose, double-blind administered in the clinic, followed by an open-label phase administered at home for the second and subsequent doses. [56]
Extensive assessment of adverse events. Claims:

"majority of adverse events had a doubtful or no relationship the treatment, and most were considered mild."

No safety claims made.
36 hours

2

2

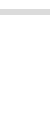




\begin{tabular}{|c|c|c|c|c|}
\hline $\begin{array}{l}\text { Sources cited for } \\
\text { safety of paracetamol } \\
\text { in children or infants: } \\
\text { study number, year, } \\
\text { and design }\end{array}$ & Study subjects & $\begin{array}{l}\text { Outcome measures } \\
\text { related to safety or } \\
\text { safety claims made. }\end{array}$ & $\begin{array}{l}\text { Duration of } \\
\text { monitoring }\end{array}$ & $\begin{array}{l}\text { Times } \\
\text { cited }\end{array}$ \\
\hline
\end{tabular}

30. 2011: Review
describing NSAIDs
and paracetamol and
their roles in reducing
side-effects after
surgery [58]

\section{2013: Review} describing dosing and antipyretic efficacy of paracetamol [59]

NA: Review

Makes no safety claim.

NA: Review

2

NA: Review Claims: "dosing range is well tolerated in children" without citation.
NA: Review

2

\section{1965.}

Pharmacology

reference book [60]

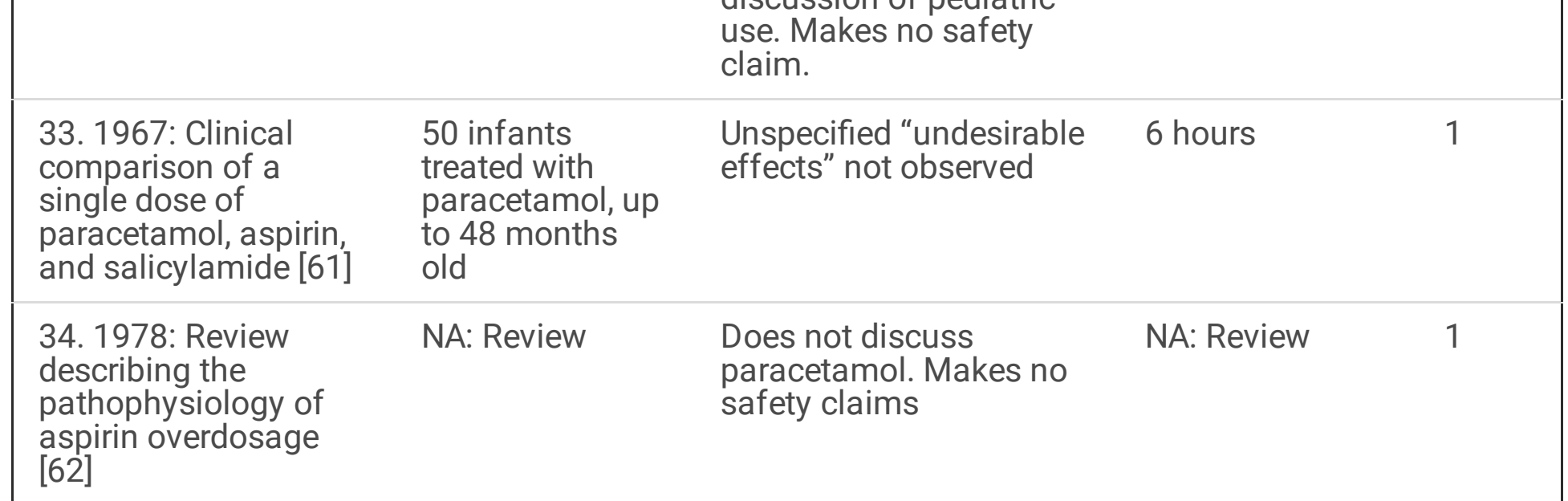

\section{5: 1982. Monitoring} of drug use by the Pediatric Drug Surveillance Program [63]

\section{1982: An abstract} [64] cited by Ragg, 1997 [65]

\section{1984: Prospective} study observing adverse drug reactions in pediatric inpatients. [66]

\section{1,158 children,} up to age 16 , received paracetamol
Adverse events not reported. Makes no safety claim
NA: Review

Pediatric dose stated without citation, and without further discussion of pediatric use. Makes no safety claim.

Unspecified "undesirable

1

NA: No follow-up 1
conducted

Not determined Not determined

Not determined

1
NA: Review
132 children, age not specified, received an antipyretic or analgesics while hospitalized (paracetamol not mentioned)
No side effects observed. No safety claims made.
During inpatient specified.

1




\begin{tabular}{|c|c|c|c|c|}
\hline $\begin{array}{l}\text { Sources cited for } \\
\text { safety of paracetamol } \\
\text { in children or infants: } \\
\text { study number, year, } \\
\text { and design }\end{array}$ & Study subjects & $\begin{array}{l}\text { Outcome measures } \\
\text { related to safety or } \\
\text { safety claims made. }\end{array}$ & $\begin{array}{l}\text { Duration of } \\
\text { monitoring }\end{array}$ & $\begin{array}{l}\text { Times } \\
\text { cited }\end{array}$ \\
\hline $\begin{array}{l}\text { 38. 1989: Editorial } \\
\text { comparing ibuprofen } \\
\text { and paracetamol [67] }\end{array}$ & NA: Editorial & $\begin{array}{l}\text { Claims: "therapeutic } \\
\text { doses of either drug } \\
\text { [ibuprofen and } \\
\text { paracetamol] cause no } \\
\text { discernable adverse } \\
\text { effects" without citation. }\end{array}$ & NA: Editorial & 1 \\
\hline $\begin{array}{l}\text { 39. 1989: Review } \\
\text { assessing pain in } \\
\text { neonates and the } \\
\text { approaches to } \\
\text { postoperative } \\
\text { analgesia }\end{array}$ & NA: Review & $\begin{array}{l}\text { Claims: "Recent data } \\
\text { have supported the } \\
\text { relative safety and } \\
\text { analgesic efficacy of } \\
\text { paracetamol in newborn } \\
\text { infants" without citation. }\end{array}$ & NA: Review & 1 \\
\hline \multicolumn{5}{|l|}{ [68] } \\
\hline $\begin{array}{l}\text { 40. 1990: } \\
\text { Pharmacology } \\
\text { reference book [69] }\end{array}$ & NA: Review & $\begin{array}{l}\text { Claims: "usually well } \\
\text { tolerated" without } \\
\text { citation, but use in } \\
\text { pediatric populations is } \\
\text { not discussed. }\end{array}$ & NA: Review & 1 \\
\hline $\begin{array}{l}\text { 41. 1991: Review } \\
\text { describing } \\
\text { paracetamol } \\
\text { hepatotoxicity and } \\
\text { poisoning in children } \\
\text { [70] }\end{array}$ & NA: Review & Makes no safety claim & NA: Review & 1 \\
\hline \multirow{3}{*}{$\begin{array}{l}\text { 42. 1992: Review } \\
\text { describing the } \\
\text { hepatotoxicity of non- } \\
\text { steroidal anti- } \\
\text { inflammatory drugs } \\
\text { [71] }\end{array}$} & \multirow[t]{3}{*}{ NA: Review } & Claims: & \multirow[t]{3}{*}{ NA: Review } & \multirow[t]{3}{*}{1} \\
\hline & & Paracetamol is & & \\
\hline & & $\begin{array}{l}\text { "normally very safe when } \\
\text { used properly" although } \\
\text { this statement does not } \\
\text { necessarily refer to } \\
\text { pediatric use }\end{array}$ & & \\
\hline $\begin{array}{l}\text { 43. 1992: } \\
\text { Randomized, double- } \\
\text { blind, multidose, } \\
\text { parallel-group, } \\
\text { variable duration } \\
\text { clinical trial with three } \\
\text { different } \\
\text { concentrations of } \\
\text { ibuprofen and one of } \\
\text { paracetamol given for } \\
\text { pediatric fever [72] }\end{array}$ & $\begin{array}{l}16 \text { children } \\
\text { treated with } \\
\text { paracetamol; } \\
\text { average age is } \\
5.2 \text { years }\end{array}$ & $\begin{array}{l}\text { Adverse events included } \\
\text { headache, } \\
\text { gastrointestinal effects, } \\
\text { sweating, hypothermia, } \\
\text { abdominal pain, } \\
\text { agitation, nervousness, } \\
\text { and adverse experiences } \\
\text { related to the respiratory } \\
\text { system. }\end{array}$ & 24 to 48 hours & 1 \\
\hline
\end{tabular}




\begin{tabular}{|lllll|}
\hline $\begin{array}{l}\text { Sources cited for } \\
\text { safety of paracetamol } \\
\text { in children or infants: } \\
\text { study number, year, }\end{array}$ & Study subjects & $\begin{array}{l}\text { Outcome measures } \\
\text { related to safety or } \\
\text { and design }\end{array}$ & $\begin{array}{l}\text { Duration of } \\
\text { monitoring }\end{array}$ & $\begin{array}{l}\text { Times } \\
\text { cited }\end{array}$ \\
\hline
\end{tabular}

44. 1994: Textbook $\quad$ NA: Textbook $\quad$ Not determined
[73] cited by Wilson,
1995. [74]

\begin{tabular}{|c|c|c|c|c|}
\hline $\begin{array}{l}\text { 45. 1996: Double-blind } \\
\text { study with two } \\
\text { treatments, } \\
\text { paracetamol and } \\
\text { placebo given for } \\
\text { postoperative pain } \\
75]\end{array}$ & $\begin{array}{l}100 \text { children } \\
\text { were treated } \\
\text { with } \\
\text { paracetamol, } \\
\text { age } 3 \text { to } \\
14 \text { years }\end{array}$ & $\begin{array}{l}\text { Liver enzymes } \\
\text { determined by blood } \\
\text { samples. }\end{array}$ & 24 hours & 1 \\
\hline
\end{tabular}

46. 1996: Randomized study with two treatment groups, one of which received paracetamol preoperatively and the other postoperatively [76]

\section{8 children, age 2 to 8 years}

Liver enzymes determined by blood samples.
Outcome measures

included pain scores and the need for rescue analgesics

\section{0 minutes}

1

47. 1997: Double-
blind, multicenter
study with two
treatments, one each
of ibuprofen and
paracetamol, given for
fever [77]

\section{1999:}

Randomized, doubleblind, placebocontrolled study with four different concentrations of paracetamol given after induction of anesthesia [78]

\section{1999: Clinical trial} examining the efficacy and pharmacokinetics of paracetamol in term infants (multipledose) [79]

50. 2000: Review describing non-opioid drugs for treatment of postoperative pain [80]
56 children

treated with

paracetamol,

11 years;

average age is

4.2 years

\section{0 children}

treated with

paracetamol, age 1 to 7 years age 8 months to
Postoperative pain was evaluated by behavioral assessment and physiologic measurement. Only side effects reported were postoperative nausea and vomiting

Changes in temperature. Only side effect reported was vomiting.

6 hours

24 hours
10 infants, up to the age of 2 days
Adverse events not reported. Claims: "paracetamol can be administered safely to neonates on the first day of life"
First 2 days after 1 birth
NA: Review
Claims: rectal

paracetamol "seems safe in children" without citation. 


\section{Sources cited for safety of paracetamol in children or infants: study number, year, and design}

51. 2000:

Pharmacokinetic study of postoperative, repeated dosing of rectal paracetamol [81]

\section{Study subjects}

21 children, age

9 weeks to

11 years

\section{Outcome measures related to safety or safety claims made.}

Duration of monitoring
Times cited $\begin{array}{lll}\text { No sign of adverse } & \text { Variable, from } 1 & 1\end{array}$ effects observed. Claims: to 5 days Paracetamol has gained wide acceptance as a simple and safe antipyretic and analgesic in children", without citation.
52. 2000:

Observational study of calls to a poison center to evaluate pediatric paracetamol exposures [82]

53. 2000: Review of paracetamol's history,
1,019 children up to the age of 7 years
Parent's report of signs of hepatotoxicity.
72 hours

1 present and future [83]
NA: Review NA: Review
Claims: paracetamol is

an "effective and remarkably safe drug when used properly" without citation

\section{2000:}

Randomized, doubleblind study with two treatments, one each of diclofenac and paracetamol for postoperative analgesia [84]

55. 2000: Integrated Management of Childhood Illness handbook by the World Health Organization [85]

56. 2000:

Randomized, doubleblind, multicenter study comparing paracetamol controlled-release sprinkles and paracetamol immediate-release elixir in febrile children [86]

\section{4 children} treated with paracetamol, age 5 to 15 years; median age is 10 years
Outcome measures used were pain scores and relief of pain or dysphagia. Only side effects reported were nausea and vomiting.
NA: Review

1

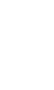




\begin{tabular}{|c|c|c|c|c|}
\hline $\begin{array}{l}\text { Sources cited for } \\
\text { safety of paracetamol } \\
\text { in children or infants: } \\
\text { study number, year, } \\
\text { and design }\end{array}$ & Study subjects & $\begin{array}{l}\text { Outcome measures } \\
\text { related to safety or } \\
\text { safety claims made. }\end{array}$ & $\begin{array}{l}\text { Duration of } \\
\text { monitoring }\end{array}$ & $\begin{array}{l}\text { Times } \\
\text { cited }\end{array}$ \\
\hline $\begin{array}{l}\text { 57. 2000: Guide to } \\
\text { pediatric medication } \\
\text { and nutrition [87] }\end{array}$ & NA: Review & $\begin{array}{l}\text { Claims: "Usually well } \\
\text { tolerated when used as } \\
\text { directed", without } \\
\text { citation. }\end{array}$ & NA: Review & 1 \\
\hline $\begin{array}{l}\text { 58. 2001: Review } \\
\text { describing treatment } \\
\text { with paracetamol in } \\
\text { infants [88] }\end{array}$ & NA: Review & $\begin{array}{l}\text { Claims: "generally } \\
\text { considered a safe drug" } \\
\text { without citation but } \\
\text { warns of potential } \\
\text { toxicity with glutathione } \\
\text { depletion. }\end{array}$ & NA: Review & 1 \\
\hline $\begin{array}{l}59.2001 \text { Literature } \\
\text { review describing } \\
\text { perioperative use of } \\
\text { high-dose of rectal } \\
\text { paracetamol [89] }\end{array}$ & NA: Review & $\begin{array}{l}\text { Claims: "administration } \\
\text { of high-dose rectal } \\
\text { paracetamol in the } \\
\text { perioperative period } \\
\text { appears to be safe" } \\
\text { without citation. }\end{array}$ & NA: Review & 1 \\
\hline $\begin{array}{l}\text { 60. 2001: Review } \\
\text { describing } \\
\text { paracetamol toxicity } \\
\text { in children [90] }\end{array}$ & NA: Review & $\begin{array}{l}\text { Claims: safety based on } \\
\text { NAPQI production and } \\
\text { glutathione levels } \\
\text { without citation. }\end{array}$ & NA: Review & 1 \\
\hline $\begin{array}{l}\text { 61. 2001: Review } \\
\text { describing the } \\
\text { neurobiology of pain } \\
\text { [91] }\end{array}$ & NA: Review & Makes no safety claim & NA: Review & 1 \\
\hline $\begin{array}{l}\text { 62. 2001: } \\
\text { Randomized, } \\
\text { stratified, placebo- } \\
\text { controlled, single- } \\
\text { dose, double-blind, } \\
\text { triple-dummy, single- } \\
\text { center, parallel-group } \\
\text { study with four } \\
\text { treatments, one each } \\
\text { of ibuprofen, } \\
\text { ketoprofen, } \\
\text { paracetamol, and } \\
\text { placebo given for } \\
\text { postoperative dental } \\
\text { pain [92] }\end{array}$ & $\begin{array}{l}\text { NA: minimum } \\
\text { age } 16 \text { years, } \\
\text { average age } \\
22.2 \text { years }\end{array}$ & $\begin{array}{l}\text { NA: minimum age } 16 \\
\text { years, average age } \\
22.2 \text { years }\end{array}$ & $\begin{array}{l}\text { NA: minimum } \\
\text { age } 16 \text { years, } \\
\text { average age } \\
22.2 \text { years }\end{array}$ & 1 \\
\hline
\end{tabular}




\begin{tabular}{|c|c|c|c|c|}
\hline $\begin{array}{l}\text { Sources cited for } \\
\text { safety of paracetamol } \\
\text { in children or infants: } \\
\text { study number, year, } \\
\text { and design }\end{array}$ & Study subjects & $\begin{array}{l}\text { Outcome measures } \\
\text { related to safety or } \\
\text { safety claims made. }\end{array}$ & $\begin{array}{l}\text { Duration of } \\
\text { monitoring }\end{array}$ & $\begin{array}{l}\text { Times } \\
\text { cited }\end{array}$ \\
\hline $\begin{array}{l}\text { 63. 2001: Blinded } \\
\text { study conducted to } \\
\text { observe the analgesic } \\
\text { efficacy of rectal and } \\
\text { oral paracetamol in } \\
\text { two separate groups } \\
\text { in children after } \\
\text { craniofacial surgery } \\
\text { [93] }\end{array}$ & $\begin{array}{l}40 \text { patients, } \\
\text { average age is } \\
10.3 \text { years }\end{array}$ & $\begin{array}{l}\text { Paracetamol plasma } \\
\text { concentrations and pain } \\
\text { scores. Only side effect } \\
\text { reported was vomiting. } \\
\text { Makes no safety claims. }\end{array}$ & 24 hours & 1 \\
\hline $\begin{array}{l}\text { 64. 2002: Review } \\
\text { comparing the effects } \\
\text { of paracetamol, } \\
\text { NSAIDs or their } \\
\text { combination in } \\
\text { postoperative pain } \\
\text { management [94] }\end{array}$ & NA: Review & $\begin{array}{l}\text { Claims: "low incidence of } \\
\text { adverse effects" without } \\
\text { citation }\end{array}$ & NA: Review & 1 \\
\hline $\begin{array}{l}\text { 65. 2002: Literature } \\
\text { review describing } \\
\text { paracetamol and } \\
\text { ibuprofen use for } \\
\text { fever treatment in } \\
\text { children [95] }\end{array}$ & NA: Review & $\begin{array}{l}\text { Claims: "Both drugs } \\
\text { appeared well tolerated } \\
\text { and no evidence of } \\
\text { difference in short-term } \\
\text { adverse effects was } \\
\text { observed" without } \\
\text { citation }\end{array}$ & NA: Review & 1 \\
\hline $\begin{array}{l}\text { 66. 2003: Editorial } \\
\text { describing use of } \\
\text { antipyretics [96] }\end{array}$ & NA: Editorial & $\begin{array}{l}\text { Claims: paracetamol is } \\
\text { "traditional(ly) } \\
\text { considered to be safe } \\
\text { based on (a) large } \\
\text { clinical experience over } \\
\text { (a) long time" without } \\
\text { citation. }\end{array}$ & NA: Editorial & 1 \\
\hline 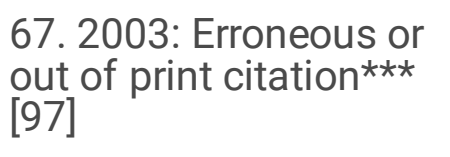 & $\begin{array}{l}\text { NA: Erroneous or } \\
\text { out of print } \\
\text { citation }\end{array}$ & $\begin{array}{l}\text { NA: Erroneous or out of } \\
\text { print citation }\end{array}$ & $\begin{array}{l}\text { NA: Erroneous or } \\
\text { out of print } \\
\text { citation }\end{array}$ & 1 \\
\hline $\begin{array}{l}\text { 68. 2003: Review } \\
\text { describing anti- } \\
\text { inflammatory agents } \\
\text { and paracetamol in } \\
\text { neonates [98] }\end{array}$ & NA: Review & $\begin{array}{l}\text { Claims: "paracetamol } \\
\text { remains the drug of } \\
\text { choice for antipyresis in } \\
\text { neonates" and "the } \\
\text { adverse effect of } \\
\text { paracetamol is more } \\
\text { favorable" without } \\
\text { citation }\end{array}$ & NA: Review & 1 \\
\hline
\end{tabular}




\section{Sources cited for safety of paracetamol in children or infants: study number, year, and design}

Randomized, doubleblind, placebocontrolled study with four treatments groups, ibuprofen, paracetamol, a combination of the two, and placebo. The purpose was to observe the analgesic efficacy of each treatment [99]

\section{2004:}

Pharmacokinetic study with a single intravenous dose of propacetamol [100]

\section{2004: Systematic} review assessing the prevalence of aspirin induced asthma in adults and children and other issues related to the syndrome [101]

\section{2005: Review} describing paracetamol's tolerability profile [102]

\section{2003:}

\section{Study subjects}

80 children

treated with age 1 to 6 years; average age is

2.7 years paracetamol,

\section{Outcome measures related to safety or safety claims made.}

Duration of monitoring
Times cited
Adverse events defined as retching, vomiting, abdominal pain, and dizziness
All children were $\quad 1$ kept in the PACU for 1.5 hours. The parents of the children were asked to record the well-being of their child until 24 hours after anesthesia.

\section{0 neonates, 24 hours after birth \\ Liver enzymes \\ determined by blood samples.}

10 hours
Makes no safety claim with respect to pediatric use.
NA: Review at therapeutic doses" although this statement
NA: Review
Claims: "Paracetamol is a very well tolerated drug without citation, does not necessarily refer to pediatric use.

\section{2005:}

Randomized, doubleblind study with three treatments, one each of ibuprofen, paracetamol, and placebo given before surgery [103]

\section{2005: Evaluation} of pain management guidelines for tonsillectomy [104]

75. 2006: Practice guidelines [105]

\section{5 children} treated with paracetamol, age 3 to

12 years
Agitation in recovery measured using Oucher's scale

\section{7 children, age 5-11 years.}

Evaluation of nausea and vomiting.

(1)




\begin{tabular}{|c|c|c|c|c|}
\hline $\begin{array}{l}\text { Sources cited for } \\
\text { safety of paracetamol } \\
\text { in children or infants: } \\
\text { study number, year, } \\
\text { and design }\end{array}$ & Study subjects & $\begin{array}{l}\text { Outcome measures } \\
\text { related to safety or } \\
\text { safety claims made. }\end{array}$ & $\begin{array}{l}\text { Duration of } \\
\text { monitoring }\end{array}$ & $\begin{array}{l}\text { Times } \\
\text { cited }\end{array}$ \\
\hline $\begin{array}{l}\text { 76. 2006: Practice } \\
\text { guideline to assist } \\
\text { poison center } \\
\text { personnel with } \\
\text { management of } \\
\text { paracetamol } \\
\text { poisoning [106] }\end{array}$ & NA: Guidelines & Makes no safety claim & NA: Guidelines & 1 \\
\hline $\begin{array}{l}\text { 77-79. 2004-2010: } \\
\text { Three textbooks [107- } \\
\text { 109] cited by Karbasi } \\
\text { and colleagues [110] }\end{array}$ & NA: Textbooks & Not determined & NA: Textbooks & 1 \\
\hline $\begin{array}{l}\text { 80. 2007: Review } \\
\text { describing } \\
\text { paracetamol safety } \\
\text { and hepatotoxicity } \\
\text { [111] }\end{array}$ & NA: Review & $\begin{array}{l}\text { Claims: "an excellent } \\
\text { overall safety record" } \\
\text { with infants and children } \\
\text { without citation }\end{array}$ & NA: Review & 1 \\
\hline $\begin{array}{l}\text { 81. 2007. Open-label, } \\
\text { single-sequence, } \\
\text { multiple-dose study } \\
\text { with intravenous } \\
\text { paracetamol in adults } \\
\text { 112] }\end{array}$ & $\begin{array}{l}\text { NA: study in } \\
\text { adults }\end{array}$ & NA: study in adults & $\begin{array}{l}\text { NA: study in } \\
\text { adults }\end{array}$ & 1 \\
\hline $\begin{array}{l}\text { 82. 2007: Randomized } \\
\text { double-blind placebo- } \\
\text { controlled study with } \\
\text { paracetamol given for } \\
\text { fever [113] }\end{array}$ & $\begin{array}{l}103 \text { children } \\
\text { treated with } \\
\text { paracetamol, } \\
\text { age } 6 \text { months to } \\
6 \text { years; average } \\
\text { age is } \\
26.1 \text { months }\end{array}$ & $\begin{array}{l}\text { Outcome measures } \\
\text { included fever clearance } \\
\text { time, rate of fall of } \\
\text { temperature, percent } \\
\text { reduction of temperature, } \\
\text { proportion of afebrile } \\
\text { children, symptomatic } \\
\text { improvement and clinical } \\
\text { and biochemical adverse } \\
\text { effects. Claims: } \\
\text { "considered to be a safe } \\
\text { drug at therapeutic } \\
\text { levels." }\end{array}$ & 6 hours & 1 \\
\hline $\begin{array}{l}\text { 83. 2007: } \\
\text { Randomized, double- } \\
\text { blind, placebo- } \\
\text { controlled study with } \\
\text { three treatments, one } \\
\text { each of naproxen, } \\
\text { paracetamol, and } \\
\text { placebo before the } \\
\text { induction of anethesia } \\
\text { [114] }\end{array}$ & $\begin{array}{l}30 \text { children } \\
\text { treated with } \\
\text { paracetamol, } \\
\text { age } 1 \text { to } 6 \text { years, } \\
\text { average age is } \\
1.3 \text { years }\end{array}$ & $\begin{array}{l}\text { Need for postoperative } \\
\text { rescue fentanyl and the } \\
\text { incidence of } \\
\text { postoperative nausea } \\
\text { and vomiting. }\end{array}$ & $\begin{array}{l}\text { Minimum of } 2 \\
\text { hours }\end{array}$ & 1 \\
\hline
\end{tabular}




\begin{tabular}{|c|c|c|c|c|}
\hline $\begin{array}{l}\text { Sources cited for } \\
\text { safety of paracetamol } \\
\text { in children or infants: } \\
\text { study number, year, } \\
\text { and design }\end{array}$ & Study subjects & $\begin{array}{l}\text { Outcome measures } \\
\text { related to safety or } \\
\text { safety claims made. }\end{array}$ & $\begin{array}{l}\text { Duration of } \\
\text { monitoring }\end{array}$ & $\begin{array}{l}\text { Times } \\
\text { cited }\end{array}$ \\
\hline $\begin{array}{l}\text { 84. 2007: Study with } \\
\text { zolmitriptan nasal } \\
\text { spray, not } \\
\text { paracetamol [115] }\end{array}$ & $\begin{array}{l}\text { NA: study not } \\
\text { involving } \\
\text { paracetamol }\end{array}$ & $\begin{array}{l}\text { NA: study not involving } \\
\text { paracetamol }\end{array}$ & $\begin{array}{l}\text { NA: study not } \\
\text { involving } \\
\text { paracetamol }\end{array}$ & 1 \\
\hline $\begin{array}{l}\text { 85. 2007: Guidelines } \\
\text { for assessment and } \\
\text { initial management of } \\
\text { fever in children } \\
\text { younger than } 5 \text { years } \\
\text { [116] }\end{array}$ & $\begin{array}{l}\text { NA: Clinical } \\
\text { guidelines }\end{array}$ & Makes no safety claim & $\begin{array}{l}\text { NA: Clinical } \\
\text { guidelines }\end{array}$ & 1 \\
\hline $\begin{array}{l}\text { 86. 2007: Review } \\
\text { describing systemic } \\
\text { analgesics for } \\
\text { children [117] }\end{array}$ & NA: Review & $\begin{array}{l}\text { Claims: "when the } \\
\text { maximum daily dose of } \\
\text { paracetamol is observed } \\
\text { it is well tolerated" } \\
\text { without citation }\end{array}$ & NA: Review & 1 \\
\hline $\begin{array}{l}\text { 87. 2009: } \\
\text { Comparative study } \\
\text { with three treatments: } \\
\text { paracetamol, } \\
\text { ketoprofen, and } \\
\text { ibuprofen given for } \\
\text { fever [118] }\end{array}$ & $\begin{array}{l}112 \text { children } \\
\text { were treated } \\
\text { with } \\
\text { paracetamol, } \\
\text { average age } \\
\text { about } 4 \text { years } \\
\text { old. }\end{array}$ & $\begin{array}{l}\text { Children were monitored } \\
\text { without observation of } \\
\text { drug-related side effects. } \\
\text { Makes no safety claim }\end{array}$ & Up to 48 hours & 1 \\
\hline $\begin{array}{l}\text { 88. Randomized, } \\
\text { controlled trial in } \\
\text { which patients } \\
\text { received either } \\
\text { paracetamol or } \\
\text { placebo for } \\
\text { postoperative pain } \\
\text { 119] }\end{array}$ & $\begin{array}{l}29 \text { infants were } \\
\text { treated with } \\
\text { paracetamol, } \\
\text { age } 0-2 \text { months }\end{array}$ & $\begin{array}{l}\text { Did not report any } \\
\text { adverse events. } \\
\text { Measured the efficacy of } \\
\text { paracetamol, not safety. }\end{array}$ & 48 hours & 1 \\
\hline $\begin{array}{l}\text { 89. 2009: Review } \\
\text { describing the Italian } \\
\text { Pediatric Society } \\
\text { guidelines on the } \\
\text { management of fever } \\
\text { in children [120] }\end{array}$ & NA: Review & $\begin{array}{l}\text { Claims: paracetamol is } \\
\text { "generally well tolerated" } \\
\text { without citation. }\end{array}$ & NA: Review & 1 \\
\hline $\begin{array}{l}\text { 90. 2009: Review } \\
\text { describing drugs of } \\
\text { choice for sedation } \\
\text { and analgesia in the } \\
\text { NICU [121] }\end{array}$ & NA: Review & Makes no safety claims & NA: Review & 1 \\
\hline
\end{tabular}




\begin{tabular}{|c|c|c|c|c|}
\hline $\begin{array}{l}\text { Sources cited for } \\
\text { safety of paracetamol } \\
\text { in children or infants: } \\
\text { study number, year, } \\
\text { and design }\end{array}$ & Study subjects & $\begin{array}{l}\text { Outcome measures } \\
\text { related to safety or } \\
\text { safety claims made. }\end{array}$ & $\begin{array}{l}\text { Duration of } \\
\text { monitoring }\end{array}$ & $\begin{array}{l}\text { Times } \\
\text { cited }\end{array}$ \\
\hline $\begin{array}{l}\text { 91. 2009: Review } \\
\text { describing the peri- } \\
\text { operative use of } \\
\text { paracetamol [122] }\end{array}$ & NA: Review & $\begin{array}{l}\text { Claims: paracetamol is a } \\
\text { "safe, well-tolerated drug } \\
\text { with proven efficacy" } \\
\text { without citation. }\end{array}$ & NA: Review & 1 \\
\hline $\begin{array}{l}\text { 92. 2009: Systematic } \\
\text { review of the clinical } \\
\text { safety and tolerability } \\
\text { of ibuprofen } \\
\text { compared with } \\
\text { paracetamol in } \\
\text { pediatric pain and } \\
\text { fever [123] }\end{array}$ & NA: Review & Makes no safety claims & NA: Review & 1 \\
\hline $\begin{array}{l}\text { 93. 2009: Online } \\
\text { survey of anesthetists } \\
\text { and the current } \\
\text { prescribing practice of } \\
\text { i.v. paracetamol [124] }\end{array}$ & NA: Survey & Makes no safety claims & NA: Survey & 1 \\
\hline $\begin{array}{l}\text { 94: 2010: } \\
\text { Hemodynamic study } \\
\text { with intravenous } \\
\text { paracetamol in } \\
\text { neonates }[125]\end{array}$ & $\begin{array}{l}72 \text { neonates, } \\
\text { age } 1 \text { to } 27 \\
\text { days; average } \\
\text { age is } 3 \text { days }\end{array}$ & $\begin{array}{l}\text { Assessment of } \\
\text { hemodynamics. No } \\
\text { safety claims made. }\end{array}$ & 6 hours & 1 \\
\hline $\begin{array}{l}\text { 95: } 2010 \text { : Review } \\
\text { describing post- } \\
\text { operative pain } \\
\text { management [126] }\end{array}$ & NA: Review & Makes no safety claim & NA: Review & 1 \\
\hline $\begin{array}{l}\text { 96: 2010: Meta- } \\
\text { analysis of efficacy } \\
\text { and safety of } \\
\text { ibuprofen and } \\
\text { paracetamol in } \\
\text { children and adults } \\
\text { [127] }\end{array}$ & NA: Review & $\begin{array}{l}\text { Claims similar safety } \\
\text { profiles between } \\
\text { paracetamol and } \\
\text { ibuprofen, but makes no } \\
\text { absolute safety claim }\end{array}$ & NA: Review & 1 \\
\hline $\begin{array}{l}\text { 97: 2011: Study of } \\
\text { efficacy and safety in } \\
\text { adults [128] }\end{array}$ & $\begin{array}{l}\text { NA: study in } \\
\text { adults }\end{array}$ & NA: study in adults & $\begin{array}{l}\text { NA: study in } \\
\text { adults }\end{array}$ & 1 \\
\hline $\begin{array}{l}\text { 98: 2011: Literature } \\
\text { review of clinical trials } \\
\text { of intravenous } \\
\text { paracetamol for } \\
\text { postoperative pain } \\
\text { [129] }\end{array}$ & NA: Review & $\begin{array}{l}\text { Claims: it "has been well } \\
\text { known as a safe and } \\
\text { effective" without } \\
\text { citation }\end{array}$ & NA: Review & 1 \\
\hline
\end{tabular}




\begin{tabular}{|c|c|c|c|c|}
\hline $\begin{array}{l}\text { Sources cited for } \\
\text { safety of paracetamol } \\
\text { in children or infants: } \\
\text { study number, year, } \\
\text { and design }\end{array}$ & Study subjects & $\begin{array}{l}\text { Outcome measures } \\
\text { related to safety or } \\
\text { safety claims made. }\end{array}$ & $\begin{array}{l}\text { Duration of } \\
\text { monitoring }\end{array}$ & $\begin{array}{l}\text { Times } \\
\text { cited }\end{array}$ \\
\hline $\begin{array}{l}\text { 99: 2012: Review of } \\
\text { efficacy and } \\
\text { pharmacokinetics of } \\
\text { paracetamol in } \\
\text { pediatric patients } \\
\text { 130] }\end{array}$ & NA: Review & Makes no safety claims & NA: Review & 1 \\
\hline $\begin{array}{l}\text { 100: 2012: } \\
\text { Retrospective study } \\
\text { using data collected } \\
\text { on pediatric surgery } \\
\text { patients to identify the } \\
\text { status and risk factors } \\
\text { of major infections } \\
\text { [24] }\end{array}$ & $\begin{array}{l}230 \text { patients, } \\
\text { age } 0 \text { to } 15 \\
\text { years, average } \\
\text { age is } 4.28 \text { years }\end{array}$ & $\begin{array}{l}\text { Postoperative fever and } \\
\text { its etiologies, mortality } \\
\text { discharge, and rates of } \\
\text { re-open sternotomy } \\
\text { reintubation }\end{array}$ & 1 year & 1 \\
\hline $\begin{array}{l}\text { 101. 2013: Case series } \\
\text { evaluating the efficacy } \\
\text { of intravenous } \\
\text { paracetamol in } \\
\text { preterm infants with } \\
\text { hemodynamically } \\
\text { significant patent } \\
\text { ductus arteriosus } \\
\text { (hsPDA) [131] }\end{array}$ & $\begin{array}{l}10 \text { preterm } \\
\text { infants, age } 2 \text { to } \\
15 \text { days }\end{array}$ & $\begin{array}{l}\text { Pre- and posttreatment } \\
\text { levels of liver enzymes }\end{array}$ & 3 days & 1 \\
\hline $\begin{array}{l}\text { 102. 2013: } \\
\text { Mechanistic study in } \\
\text { laboratory animals } \\
\text { [132] }\end{array}$ & $\begin{array}{l}\text { NA: Study in } \\
\text { laboratory } \\
\text { animals }\end{array}$ & Makes no safety claim & $\begin{array}{l}\text { NA: Study in } \\
\text { laboratory } \\
\text { animals }\end{array}$ & 1 \\
\hline $\begin{array}{l}\text { 103. 2014. Literature } \\
\text { review assessing liver } \\
\text { toxicity due to } \\
\text { paracetamol in } \\
\text { children [133] }\end{array}$ & NA: Review & $\begin{array}{l}\text { Claims: "doses of less } \\
\text { than } 75 \\
\mathrm{mg} / \mathrm{kg} / \text { day of } \\
\text { paracetamol are safe for } \\
\text { children younger than } \\
6 \text { years of age" without } \\
\text { citation }\end{array}$ & NA: Review & 1 \\
\hline
\end{tabular}

In the fourth step, any discrepancies between the analyses provided by coauthors JCH and JTS were arbitrated by coauthor WP. In the fifth step, articles upon which safety claims were based were compiled. Finally, articles upon which safety claims were based and which contained experiments designed to assess safety were evaluated. For each experiment described, the study group, endpoints measured, and follow-up time were evaluated.

\section{Results}


An overview of results from a systematic search for studies demonstrating safety of paracetamol use in infants and children is shown in Table 1. The initial Medline search provided 3096 articles that contained the terms infant and either paracetamol or acetaminophen that were published between 1974 and 2017. From these articles, 467 were selected for assessment based on likelihood of safety claims regarding use of paracetamol in infants or children. Of these 467 articles, 218 made safety claims regarding the use of paracetamol in infants or children. During this phase of the study, numerous articles were identified which either claimed or demonstrated that paracetamol use, even at doses beyond the recommended dose, does not generally cause long-term liver damage in infants or children. Any claims of safety for liver function were not evaluated in detail and were not considered in this study. Only general claims of safety were assessed.

Of the 218 articles making claims that paracetamol use in infants or children is safe, half (114) provided no citation. The other half (114) of the articles cited additional articles as evidence that paracetamol is safe in infants or children. Cited articles were carefully evaluated as described in the methods. In some cases, those "primary" cited articles did not make original claims of safety, but rather cited additional ("secondary") articles. In cases where a primary article cited another article, the primary article was not considered to have made an original claim of safety, and was not evaluated further. An example of the results of this process is shown in Fig. 1. Both primary articles and secondary (and tertiary, etc) articles attributed with claims of the safety of paracetamol use in infants or children were compiled and are shown in Table 2. In total, 103 articles were identified which were cited as containing original claims that paracetamol use in infants or children is safe when used as directed.

Several studies emerged as popular citations for the claim that paracetamol use in infants or children is safe when used as directed. Only 19 articles were cited more than twice, and the most popular article [22] was cited a total of 13 times (Table 2) by the 218 articles we identified. However, in some cases, well cited articles did not make original claims of safety, and are therefore not included in Table 2. For example, an article by Perrott and colleagues in 2004 [23] was cited a total of 7 total times by the 218 articles we identified. However, Perrott's article, being a review, does not make original claims of safety, but rather cites additional articles as the authority for assurance of safety (Fig. 1). Thus, Perrott's article is not included in Table 2 as an original source for the claim that use of paracetamol is safe for infants and children when used as directed.

Of the 103 articles cited as authority for the safety of paracetamol use in infants or children, 27 did not make claims of safety and did not address safety experimentally (Table 2). Thus, 76 of the 103 articles did address safety, and 48 of these (63\%) had already been identified in the original 218 articles culled from the Medline search. Of the 103 articles, 36 articles described experimental studies which involved paracetamol use in infants or children. Although several of these studies provided measures of liver function (Table 2), none of these 36 studies provided any assessment of neuropsychiatric function. Further, the median follow-up time of all 36 studies was 24 hours (Fig. 2), far too short to identify any long-term effects of drug exposure on neuropsychiatric function. Four studies had a follow-up time of longer than 10 days, with one study in particular [24] evaluating patients out to one year. However, these 
studies were blind to any potential effects of drug exposure on long-term neuropsychiatric function. For example, although patients were followed for a full year in one study [24], the only endpoint measured was re-admission for surgery.

The path from more recent papers to the original research addressing the safety of paracetamol in infants and children was sometimes convoluted. In one notable case, a popular citation did not did appear the literature (Table 2). Not only did the volume and journal number not match, but the title could not be found elsewhere. As another example, the citations reporting safety of paracetamol use in children reported by Temple and colleagues in 2017 [25] are illustrated in Fig. 1. This article provides a detailed description of three prior reports to the European Medicines Agency (reports 24570, 24571, and 47402) which, together, according to the authors, "confirm that the recommended standard paracetamol dose of 10 to $15 \mathrm{mg} / \mathrm{kg}$ is a safe and effective dose for use in pediatric patients when administered as a single dose or as multiple doses for up to 72 hours." However, the only safety measure used in the three studies was ALT levels as a marker for liver function, assessed for a maximum of 72 hours. In addition to the three reports described in their publication, Temple and colleagues cite 10 additional articles as sources for safety, including the claim that paracetamol has a "well-established efficacy and favorable safety profile" (Fig. 1). Among these 10 papers is a clinical trial [26] that addresses efficacy but not safety, and refers to two other papers that address safety, one by Lesko [22]. The paper by Lesko contradicts the view that paracetamol is safe, finding that paracetamol is significantly worse than ibuprofen in terms of risk for outpatient visits following treatment of children with asthma. Another of the articles cited by Temple in 2017, a review written by Temple more than 30 years before [27], cites a paper in the Federal Register [28] as the source for the statement that "Paracetamol is relatively free of side effects and has a wide margin of safety between therapeutic doses and toxic doses." The document in the Federal Register [28], a lengthy treatise primarily focused on determination of the appropriate dose for adults of salicylates in general and aspirin in particular, in turn cites two papers involving safety studies of paracetamol in the human pediatric population. One of those studies [29] evaluated 98 children using a blinded approach comparing aspirin and paracetamol, and monitored the children for only 6 hours. The other study [30] monitored 20 children following administration of both aspirin and paracetamol. In that study, monitoring occurred for 6 hours or less and no information was provided regarding particular side effects that were being assessed. Importantly, the Federal Register [28] attributed their view that paracetamol has "a wide range of safety" to laboratory animal studies showing that the lethal dose of paracetamol is significantly greater than the dose administered to humans. Unfortunately, studies had not been conducted at that time showing that paracetamol induces permanent neurodevelopmental injury in laboratory animals at far lower doses than the lethal dose $[15,16]$, similar to doses administered to infants and children.

\section{Discussion}

Our initial search of the PubMed® Database and review of more than 3000 titles and abstracts yielded 218 papers making claims that paracetamol is safe for infants and children when used as directed. Claims of safety in those 218 papers were traced back to 103 articles shown in Table 2, but less than 20 
of those were cited more than twice, indicating that a limited number of studies are considered key or cornerstone to the view that paracetamol is safe for use in infants or children.

This study confirms the view that paracetamol use in infants and children is widely thought to be safe when used as directed, without reservations or caveats. The fact that 27 out of 103 citations did not, in fact, demonstrate safety or make safety claims might suggest that the safety of paracetamol is taken for granted, and is not carefully considered. This view is supported by the observation that one popular citation for safety does not exist in the literature.

\section{Conclusions}

Despite apparently being taken for granted, this study demonstrates that paracetamol was never shown to be safe for neurodevelopment. This conclusion is consistent with emerging studies showing a connection between paracetamol use during development and long term neuropsychiatric disfunction as described in the Introduction. This conclusion is also consistent with emerging studies in animal models showing exquisite sensitivity of long-term behavior to early life exposure to paracetamol at neartherapeutic doses.

Although not the intended purpose of this systematic review, it demonstrated that paracetamol has been proven safe for liver function in infants and in small children, even at doses higher than those currently recommended. During the course of this review, an assumption was repeatedly encountered: because the target of paracetamol toxicity in adults is the liver, demonstration of safety in infants and children need only be tested in the liver. This assumption was/is held despite the fact that the target tissue for drug function is in the central nervous system, not the liver. A similar assumption has proven tragically fatal in the past, when it was assumed that metabolism of the antibiotic chloramphenicol was the same in infants as in adults. In that case, administration of the drug in infants led to a number of deaths [31-33] before the problem was identified.

\section{List Of Abbreviations}

BMI, body mass index.

\section{Declarations}

Ethical Approval and Consent to participate: Not applicable

Consent for publication: Not applicable.

Availability of supporting data: The dataset analyzed (PubMed( $\left.{ }^{\circledR}\right)$ is in the public domain.

Competing interests: The authors declare that they have no competing interests.

Funding: Not applicable 
Authors' contributions: JCH, JTS, VGL, AP and WP reviewed and analyzed the thousands of published papers identified in this study. $L G H, V L$, and WP designed the study and drafted the manuscript. In addition, VL performed the literature search.

Acknowledgements: The authors wish to thank John and Susan Poulton for their encouragement and support of this work.

Authors' information: Not applicable

\section{References}

1. Parker, W., et al., The role of oxidative stress, inflammation and acetaminophen exposure from birth to early childhood in the induction of autism. Journal of International Medical Research, 2017. 45(2): p. 407-438.

2. Stergiakouli, E., A. Thapar, and G. Davey Smith, Association of Acetaminophen Use During Pregnancy With Behavioral Problems in Childhood: Evidence Against Confounding. JAMA Pediatr, 2016. 170(10): p. 964-970.

3. Brandlistuen, R.E., et al., Prenatal paracetamol exposure and child neurodevelopment: a siblingcontrolled cohort study. International Journal of Epidemiology, 2013. 42(6): p. 1702-1713.

4. Liew, Z., et al., Acetaminophen use during pregnancy, behavioral problems, and hyperkinetic disorders. JAMA Pediatr, 2014. 168(4): p. 313-20.

5. Liew, Z., et al., Paracetamol use during pregnancy and attention and executive function in offspring at age 5 years. Int J Epidemiol, 2016. 45(6): p. 2009-2017.

6. Thompson, J.M., et al., Associations between acetaminophen use during pregnancy and ADHD symptoms measured at ages 7 and 11 years. PLoS One, 2014. 9(9): p. e108210.

7. Liew, Z., et al., Prenatal Use of Acetaminophen and Child IQ: A Danish Cohort Study. Epidemiology, 2016. 27(6): p. 912-8.

8. Liew, Z., et al., Maternal use of acetaminophen during pregnancy and risk of autism spectrum disorders in childhood: A Danish national birth cohort study. Autism Res, 2016. 9(9): p. 951-8.

9. Avella-Garcia, C.B., et al., Acetaminophen use in pregnancy and neurodevelopment: attention function and autism spectrum symptoms. Int J Epidemiol, 2016. 45(6): p. 1987-1996.

10. Skovlund, E., et al., Language competence and communication skills in 3-year-old children after prenatal exposure to analgesic opioids. Pharmacoepidemiol Drug Saf, 2017. 26(6): p. 625-634.

11. Vlenterie, R., et al., Neurodevelopmental problems at 18 months among children exposed to paracetamol in utero: a propensity score matched cohort study. Int J Epidemiol, 2016. 45(6): p. 19982008.

12. Ystrom, E., et al., Prenatal Exposure to Acetaminophen and Risk of ADHD. Pediatrics, 2017. 140(5).

13. Ji, Y., et al., Association of Cord Plasma Biomarkers of In Utero Acetaminophen Exposure With Risk of Attention-Deficit/Hyperactivity Disorder and Autism Spectrum Disorder in Childhood. JAMA 
Psychiatry, 2019: p. 1-11.

14. Bittker, S.S. and K.R. Bell, Acetaminophen, antibiotics, ear infection, breastfeeding, vitamin D drops, and autism: an epidemiological study. Neuropsychiatr Dis Treat, 2018. 14: p. 1399-1414.

15. Philippot, G., et al., Adult neurobehavioral alterations in male and female mice following developmental exposure to paracetamol (acetaminophen): characterization of a critical period. J Appl Toxicol, 2017. 37(10): p. 1174-1181.

16. Viberg, H., et al., Paracetamol (Acetaminophen) Administration During Neonatal Brain Development Affects Cognitive Function and Alters Its Analgesic and Anxiolytic Response in Adult Male Mice. Toxicological Sciences, 2013. 138(1): p. 139-147.

17. Hay-Schmidt, A., et al., Prenatal exposure to paracetamol/acetaminophen and precursor aniline impairs masculinisation of male brain and behaviour. Reproduction, 2017. 154(2): p. 145-152.

18. Schultz, S.T., et al., Acetaminophen (paracetamol) use, measles-mumps-rubella vaccination, and autistic disorder. The results of a parent survey. Autism, 2008. 12(3): p. 293-307.

19. Frisch, M. and J. Simonsen, Ritual circumcision and risk of autism spectrum disorder in 0-to 9-yearold boys: national cohort study in Denmark. Journal of the Royal Society of Medicine, 2015. 108(7): p. 266-279.

20. Goin-Kochel, R.P., S.S. Mire, and A.G. Dempsey, Emergence of autism spectrum disorder in children from simplex families: relations to parental perceptions of etiology. J Autism Dev Disord, 2015. 45(5): p. 1451-63.

21. Mercer, L., et al., Parental perspectives on the causes of an autism spectrum disorder in their children. J Genet Couns, 2006. 15(1): p. 41-50.

22. Lesko, S.M. and A.A. Mitchell, The safety of acetaminophen and ibuprofen among children younger than two years old. Pediatrics, 1999. 104(4): p. e39.

23. Perrott, D.A., et al., Efficacy and safety of acetaminophen vs ibuprofen for treating children's pain or fever: a meta-analysis. Arch Pediatr Adolesc Med, 2004. 158(6): p. 521-6.

24. Vijarnsorn, C., et al., Postoperative fever and major infections after pediatric cardiac surgery. J Med Assoc Thai, 2012. 95(6): p. 761-70.

25. Temple, A.R., et al., Comparison of the Efficacy and Safety of 2 Acetaminophen Dosing Regimens in Febrile Infants and Children: A Report on 3 Legacy Studies. The journal of pediatric pharmacology and therapeutics : JPPT : the official journal of PPAG, 2017. 22(1): p. 22-32.

26. Shepherd, M. and R. Aickin, Paracetamol versus ibuprofen: a randomized controlled trial of outpatient analgesia efficacy for paediatric acute limb fractures. Emerg Med Australas, 2009. 21(6): p. 484-90.

27. Temple, A.R., Review of comparative antipyretic activity in children. Am J Med, 1983. 75(5a): p. 3846.

28. Federal Register. 1977. 42(131): p. 35366-35413. 
29. Tarlin, L., et al., A comparison of the antipyretic effect of acetaminophen and aspirin. Another approach to poison prevention. Am J Dis Child, 1972. 124(6): p. 880-2.

30. Steele, R.W., et al., Oral Antipyretic Therapy: Evaluation of Aspirin-Acetaminophen Combination. American Journal of Diseases of Children, 1972. 123(3): p. 204-206.

31. Lischner, H., et al., An outbreak of neonatal deaths among term infants associated with administration of chloramphenicol. The Journal of Pediatrics, 1961. 59(1): p. 21-34.

32. Sutherland, J.M., Fatal cardiovascular collapse of infants receiving large amounts of chloramphenicol. AMA J Dis Child, 1959. 97(6): p. 761-7.

33. Burns, L.E., J.E. Hodgman, and A.B. Cass, Fatal circulatory collapse in premature infants receiving chloramphenicol. N Engl J Med, 1959. 261: p. 1318-21.

34. Hämäläinen, M.L., et al., Ibuprofen or acetaminophen for the acute treatment of migraine in children: a double-blind, randomized, placebo-controlled, crossover study. Neurology, 1997. 48(1): p. 103-7.

35. Rumack, B.H., Aspirin versus acetaminophen: a comparative view. Pediatrics, 1978. 62(5 Pt 2 Suppl): p. 943-6.

36. Litalien, C. and E. Jacqz-Aigrain, Risks and benefits of nonsteroidal anti-inflammatory drugs in children: a comparison with paracetamol. Paediatr Drugs, 2001. 3(11): p. 817-58.

37. Drwal-Klein, L.A. and S.J. Phelps, Antipyretic therapy in the febrile child. Clin Pharm, 1992. 11(12): p. 1005-21.

38. Sullivan, J.E. and H.C. Farrar, Fever and antipyretic use in children. Pediatrics, 2011. 127(3): p. 580-7.

39. Temple, A.R., Pediatric dosing of acetaminophen. Pediatr Pharmacol (New York), 1983. 3(3-4): p. 3217.

40. Lesko, S.M. and A.A. Mitchell, An assessment of the safety of pediatric ibuprofen. A practitionerbased randomized clinical trial. Jama, 1995. 273(12): p. 929-33.

41. Society, C.P., Acetaminophen and ibuprofen in the management of fever and mild to moderate pain in children Pediatr Child Health, 1998. 3(4): p. 273-274.

42. American Academy of Pediatrics Committee on Drugs: Commentary on acetaminophen. Pediatrics, 1978. 61(1): p. 108-12.

43. Lovejoy, F.H., Jr., Aspirin and acetaminophen: a comparative view of their antipyretic and analgesic activity. Pediatrics, 1978. 62(5 Pt 2 Suppl): p. 904-9.

44. Prescott, L.F., Paracetamol overdose, in Paracetamol (acetaminophen): A Critical Bibliographic Review. 1996, Taylor \& Francis Ltd. p. 451.

45. Lesko, S.M. and A.A. Mitchell, Renal function after short-term ibuprofen use in infants and children. Pediatrics, 1997. 100(6): p. 954-7.

46. Anderson, B.J., et al., Pediatric intravenous paracetamol (propacetamol) pharmacokinetics: a population analysis. Paediatr Anaesth, 2005. 15(4): p. 282-92.

47. Zuppa, A.F., et al., Safety and population pharmacokinetic analysis of intravenous acetaminophen in neonates, infants, children, and adolescents with pain or Fever. J Pediatr Pharmacol Ther, 2011. 
16(4): p. 246-61.

48. Sutton, E. and L.F. Soyka, How safe is acetaminophen? Some practical cautions with this widely used agent. Clin Pediatr (Phila), 1973. 12(12): p. 692-6.

49. Yaffe, S.J., Comparative Efficacy of Aspirin and Acetaminophen in the Reduction of Fever in Children. Archives of Internal Medicine, 1981. 141(3): p. 286-292.

50. Depré, M., et al., Tolerance and pharmacokinetics of propacetamol, a paracetamol formulation for intravenous use. Fundam Clin Pharmacol, 1992. 6(6): p. 259-62.

51. Anand, K.J.S., B.S. Shapiro, and C.B. Berde, Pharmacotherapy with systemic analgesics, in Pain Research and Clinical Management, K.J.S. Anand and P.J. McGrath, Editors. 1993: Elsevier, New York. p. 155-198.

52. Mclntyre, J. and D. Hull, Comparing efficacy and tolerability of ibuprofen and paracetamol in fever. Archives of disease in childhood, 1996. 74(2): p. 164-167.

53. Anderson, B.J. and N.H.G. Holford, Rectal paracetamol dosing regimens: determination by computer simulation. Pediatric Anesthesia, 1997. 7(6): p. 451-455.

54. Birmingham, P.K., et al., Twenty-four-hour pharmacokinetics of rectal acetaminophen in children: an old drug with new recommendations. Anesthesiology, 1997. 87(2): p. 244-52.

55. van Lingen, R.A., et al., Pharmacokinetics and metabolism of rectally administered paracetamol in preterm neonates. Archives of disease in childhood. Fetal and neonatal edition, 1999. 80(1): p. F59F63.

56. Autret-Leca, E., I.A. Gibb, and M.A. Goulder, Ibuprofen versus paracetamol in pediatric fever: objective and subjective findings from a randomized, blinded study. Curr Med Res Opin, 2007. 23(9): p. 220511.

57. Allegaert, K., et al., Hepatic tolerance of repeated intravenous paracetamol administration in neonates. Paediatr Anaesth, 2008. 18(5): p. 388-92.

58. Maund, E., et al., Paracetamol and selective and non-selective non-steroidal anti-inflammatory drugs for the reduction in morphine-related side-effects after major surgery: a systematic review. $\mathrm{Br} \mathrm{J}$ Anaesth, 2011. 106(3): p. 292-7.

59. Temple, A.R., B.R. Temple, and E.K. Kuffner, Dosing and antipyretic efficacy of oral acetaminophen in children. Clin Ther, 2013. 35(9): p. 1361-75.e1-45.

60. Woodbury, D., Analgesics and Antipyretics, in The Pharmacological Basis of Therapeutics, L. Goodman and A. Gilman, Editors. 1965, The Macmillan Company: Ney York, NY. p. 330-335.

61. Eden, A.N. and A. Kaufman, Clinical Comparison of Three Antipyretic Agents. American Journal of Diseases of Children, 1967. 114(3): p. 284-287.

62. Temple, A.R., Pathophysiology of aspirin overdosage toxicity, with implications for management. Pediatrics, 1978. 62(5 Pt 2 Suppl): p. 873-6.

63. Mitchell, A.A., et al., Acetaminophen and Aspirin: Prescription, Use, and Accidental Ingestion Among Children. American Journal of Diseases of Children, 1982. 136(11): p. 976-979. 
64. Nahata, M. and D. Powell, Kinetics of acetaminophen (AC) following single strength (SS-AC) vs double strength (DS-AC) administration to febrile children. Clinical Research, 1982. 30(2).

65. Ragg, P. and A. Davidson, Comparison of the Efficacy of Paracetamol versus Paracetamol, Codeine and Promethazine (Painstop ${ }^{\circledR}$ ) for Premedication and Analgesia for Myringotomy in Children. Anaesthesia and Intensive Care, 1997. 25(1): p. 29-32.

66. Choonara, I.A. and F. Harris, Adverse drug reactions in medical inpatients. Arch Dis Child, 1984. 59(6): p. $578-80$.

67. Ibuprofen vs Acetaminophen in Children. The Medical Letter on Drugs and Therapeutics, 1989. 31(807): p. 109-110.

68. Truog, R. and K.J. Anand, Management of pain in the postoperative neonate. Clin Perinatol, 1989. 16(1): p. 61-78.

69. Insel, P., Analgesic-antipyretics and anti-inflammatory agents; drugs employed in the treatment of rheumatoid arthritis and gout, in The Pharmacological Basis of Therapeutics, A. Gilman, et al., Editors. 1990, Pergamon Press: Elmsford, NY. p. 656-659.

70. Penna, A. and N. Buchanan, Paracetamol poisoning in children and hepatotoxicity. British journal of clinical pharmacology, 1991. 32(2): p. 143-149.

71. Prescott, L.F., The hepatotoxicity of non-steroidal anti-inflammatory drugs, in Side-Effects of AntiInflammatory Drugs 3, K.D. Rainsford and G.P. Velo, Editors. 1992, Springer Netherlands: Dordrecht. p. 176-187.

72. Walson, P.D., et al., Comparison of multidose ibuprofen and acetaminophen therapy in febrile children. Am J Dis Child, 1992. 146(5): p. 626-32.

73. Lorin, M.I., Pathogenesis of fever and its treatment, in Principles and Practice of Pediatrics, F.A. Oski and C.D. Deangelis, Editors. 1994, J.B. Lippincott: Philadelphia. p. 1111-1113.

74. Wilson, D., Assessing and managing the febrile child. Nurse Pract, 1995. 20(11 Pt 1): p. 59-60, 68-74.

75. Anderson, B., S. Kanagasundarum, and G. Woollard, Analgesic efficacy of paracetamol in children using tonsillectomy as a pain model. Anaesth Intensive Care, 1996. 24(6): p. 669-73.

76. Romej, M., et al., Effect of preemptive acetaminophen on postoperative pain scores and oral fluid intake in pediatric tonsillectomy patients. Aana j, 1996. 64(6): p. 535-40.

77. Vauzelle-Kervroëdan, F., et al., Equivalent antipyretic activity of ibuprofen and paracetamol in febrile children. J Pediatr, 1997. 131(5): p. 683-7.

78. Korpela, R.M.D., P.M.D. Korvenoja, and Olli A.M.D.P. Meretoja, Morphine-sparing Effect of Acetaminophen in Pediatric Day-case Surgery Anesthesiology: The Journal of the American Society of Anesthesiologists, 1999. 91(2): p. 442-447.

79. van Lingen, R.A., et al., Multiple-dose pharmacokinetics of rectally administered acetaminophen in term infants. Clinical Pharmacology \& Therapeutics, 1999. 66(5): p. 509-515.

80. Dahl, V. and J.C. Raeder, Non-opioid postoperative analgesia. Acta Anaesthesiol Scand, 2000. 44(10): p. 1191-203. 
81. Hahn, T.W., et al., Pharmacokinetics of rectal paracetamol after repeated dosing in children. BJA: British Journal of Anaesthesia, 2000. 85(4): p. 512-519.

82. Mohler, C.R., et al., Prospective evaluation of mild to moderate pediatric acetaminophen exposures. Ann Emerg Med, 2000. 35(3): p. 239-44.

83. Prescott, L.F., Paracetamol: past, present, and future. Am J Ther, 2000. 7(2): p. 143-7.

84. Rømsing, J., et al., Diclofenac or acetaminophen for analgesia in paediatric tonsillectomy outpatients. Acta Anaesthesiologica Scandinavica, 2000. 44(3): p. 291-295.

85. World Health, O., Handbook: IMCl Integrated Management of Childhood IIIness. 2000, World Health Organization: Geneva.

86. Wilson, J.T., et al., Acetaminophen controlled-release sprinkles versus acetaminophen immediaterelease elixir in febrile children. J Clin Pharmacol, 2000. 40(4): p. 360-9.

87. Zenk, K., J. Sills, and R. Koeppel, Neonatal Medications \& Nutrition: A Comprehensive Guide. 2nd ed. , C. Rait, Editor. 2000, NICU INK Book Publishers: Santa Rosa, CA. p. 1-7.

88. Arana, A., N.S. Morton, and T.G. Hansen, Treatment with paracetamol in infants. Acta Anaesthesiol Scand, 2001. 45(1): p. 20-9.

89. Buck, M.L., Perioperative use of high-dose rectal acetaminophen. Pediatric Pharmacotherapy, 2001. 7(9).

90. Acetaminophen Toxicity in Children. Pediatrics, 2001. 108(4): p. 1020.

91. Fitzgerald, M. and S. Beggs, The neurobiology of pain: developmental aspects. Neuroscientist, 2001. 7(3): p. 246-57.

92. Olson, N.Z., et al., Onset of analgesia for liquigel ibuprofen $400 \mathrm{mg}$, acetaminophen $1000 \mathrm{mg}$, ketoprofen $25 \mathrm{mg}$, and placebo in the treatment of postoperative dental pain. J Clin Pharmacol, 2001. 41(11): p. 1238-47.

93. van der Marel, C.D., et al., Analgesic efficacy of rectal versus oral acetaminophen in children after major craniofacial surgery. Clin Pharmacol Ther, 2001. 70(1): p. 82-90.

94. Hyllested, M., et al., Comparative effect of paracetamol, NSAIDs or their combination in postoperative pain management: a qualitative review. Br J Anaesth, 2002. 88(2): p. 199-214.

95. Purssell, E., Treating fever in children: paracetamol or ibuprofen? Br J Community Nurs, 2002. 7(6): p. 316-20.

96. Amdekar, Y.K., Rational use of antipyretics. Indian Pediatr, 2003. 40(6): p. 541-4.

97. Kehlet, H. and M.U. Werner, [Role of paracetamol in the acute pain management]. Drugs, 2003. 63 Spec No 2: p. 15-22.

98. Morris, J.L., D.A. Rosen, and K.R. Rosen, Nonsteroidal Anti-Inflammatory Agents in Neonates. Pediatric Drugs, 2003. 5(6): p. 385-405.

99. Viitanen, H., et al., Analgesic efficacy of rectal acetaminophen and ibuprofen alone or in combination for paediatric day-case adenoidectomy. Br J Anaesth, 2003. 91(3): p. 363-7. 
100. Allegaert, K., et al., Pharmacokinetics of single dose intravenous propacetamol in neonates: effect of gestational age. Archives of disease in childhood. Fetal and neonatal edition, 2004. 89(1): p. F25F28.

101. Jenkins, C., J. Costello, and L. Hodge, Systematic review of prevalence of aspirin induced asthma and its implications for clinical practice. Bmj, 2004. 328(7437): p. 434.

102. Graham, G.G., K.F. Scott, and R.O. Day, Tolerability of paracetamol. Drug Saf, 2005. 28(3): p. 227-40.

103. Kashefi, P. and M. Mirdamadi, Preemptive Analgesia with Ibuprofen and Acetaminophen in Pediatric Lower Abdominal Surgery. 2005, 2005. 10(4): p. 5.

104. White, M.C. and J.A. Nolan, An evaluation of pain and postoperative nausea and vomiting following the introduction of guidelines for tonsillectomy. Pediatric Anesthesia, 2005. 15(8): p. 683-688.

105. Batton, D.G., K.J. Barrington, and C. Wallman, Prevention and management of pain in the neonate: an update. Pediatrics, 2006. 118(5): p. 2231-41.

106. Dart, R.C., et al., Acetaminophen poisoning: an evidence-based consensus guideline for out-ofhospital management. Clin Toxicol (Phila), 2006. 44(1): p. 1-18.

107. Lorin, M.I., Fever, in Text book of pediatrics infectious disease, R.D. Feigin, et al., Editors. 2004, Saunders: Philadelphia, PA. p. 100-105.

108. Keith, R.P., Fever, in Nelson Textbook of Pediatrics, R.E. Behrman, R.M. Kliegman, and H.B. Jenson, Editors. 2007, WB Saunders: Philadelphia, PA. p. 1084-1087.

109. Jenson, H.B. and R.S. Baltimore, Infectious disease, in Nelson Essential of Pediatrics, R.E. Behrman and R.M. Kliegman, Editors. 2006, Elsevier Saunders: Philadelphia. p. 446-450.

110. Karbasi, S.A., M. Modares-Mosadegh, and M. Golestan, Comparison of antipyretic effectiveness of equal doses of rectal and oral acetaminophen in children. J Pediatr (Rio J), 2010. 86(3): p. 228-32.

111. Amar, P. and E. Schiff, Acetaminophen safety and hepatotoxicity - Where do we go from here? Expert opinion on drug safety, 2007. 6: p. 341-55.

112. Gregoire, N., et al., Safety and pharmacokinetics of paracetamol following intravenous administration of $5 \mathrm{~g}$ during the first $24 \mathrm{~h}$ with a 2-g starting dose. Clin Pharmacol Ther, 2007. 81(3): p. 401-5.

113. Gupta, $\mathrm{H}$. , et al., Role of paracetamol in treatment of childhood Fever: a double-blind randomized placebo controlled trial. Indian Pediatr, 2007. 44(12): p. 903-11.

114. Korpela, R., et al., Oral naproxen but not oral paracetamol reduces the need for rescue analgesic after adenoidectomy in children. Acta Anaesthesiol Scand, 2007. 51(6): p. 726-30.

115. Lewis, D.W., et al., Efficacy of zolmitriptan nasal spray in adolescent migraine. Pediatrics, 2007. 120(2): p. 390-6.

116. Richardson, M., et al., Assessment and initial management of feverish illness in children younger than 5 years: summary of NICE guidance. BMJ (Clinical research ed.), 2007. 334(7604): p. 11631164. 
117. Rose, M., Systemic analgesics for children. Anaesthesia \& Intensive Care Medicine, 2007. 8(5): p. 184-188.

118. Celebi, S., et al., Antipyretic Effect of Ketoprofen. The Indian Journal of Pediatrics, 2009. 76: p. 287291.

119. van der Marel, C.D., et al., Rectal acetaminophen does not reduce morphine consumption after major surgery in young infants. BJA: British Journal of Anaesthesia, 2007. 98(3): p. 372-379.

120. Chiappini, E., et al., Management of fever in children: summary of the Italian Pediatric Society guidelines. Clin Ther, 2009. 31(8): p. 1826-43.

121. Hall, R.W. and R.M. Shbarou, Drugs of choice for sedation and analgesia in the neonatal ICU. Clinics in perinatology, 2009. 36(1): p. 15-26.

122. Oscier, C.D. and Q.J. Milner, Peri-operative use of paracetamol. Anaesthesia, 2009. 64(1): p. 65-72.

123. Southey, E.R., K. Soares-Weiser, and J. Kleijnen, Systematic review and meta-analysis of the clinical safety and tolerability of ibuprofen compared with paracetamol in paediatric pain and fever. Curr Med Res Opin, 2009. 25(9): p. 2207-22.

124. Wilson-Smith, E.M. and N.S. Morton, Survey of i.v. paracetamol (acetaminophen) use in neonates and infants under 1 year of age by UK anesthetists. Paediatr Anaesth, 2009. 19(4): p. 329-37.

125. Allegaert, K. and G. Naulaers, Haemodynamics of intravenous paracetamol in neonates. Eur J Clin Pharmacol, 2010. 66(9): p. 855-8.

126. Elvir-Lazo, O.L. and P.F. White, The role of multimodal analgesia in pain management after ambulatory surgery. Curr Opin Anaesthesiol, 2010. 23(6): p. 697-703.

127. Pierce, C.A. and B. Voss, Efficacy and safety of ibuprofen and acetaminophen in children and adults: a meta-analysis and qualitative review. Ann Pharmacother, 2010. 44(3): p. 489-506.

128. Kett, D.H., et al., A randomized study of the efficacy and safety of intravenous acetaminophen vs. intravenous placebo for the treatment of fever. Clin Pharmacol Ther, 2011. 90(1): p. 32-9.

129. Macario, A. and M.A. Royal, A literature review of randomized clinical trials of intravenous acetaminophen (paracetamol) for acute postoperative pain. Pain Pract, 2011. 11(3): p. 290-6.

130. Ji, P., et al., Regulatory review of acetaminophen clinical pharmacology in young pediatric patients. J Pharm Sci, 2012. 101(12): p. 4383-9.

131. Oncel, M.Y., et al., Intravenous paracetamol treatment in the management of patent ductus arteriosus in extremely low birth weight infants. Neonatology, 2013. 103(3): p. 166-9.

132. Engström Ruud, L., et al., Acetaminophen reduces lipopolysaccharide-induced fever by inhibiting cyclooxygenase-2. Neuropharmacology, 2013. 71: p. 124-9.

133. Heard, K., et al., Toxicity from repeated doses of acetaminophen in children: assessment of causality and dose in reported cases. Am J Ther, 2014. 21(3): p. 174-83.

134. Cranswick, N. and D. Coghlan, Paracetamol Efficacy and Safety in Children: the First 40 Years. American Journal of Therapeutics, 2000. 7: p. 135142. 


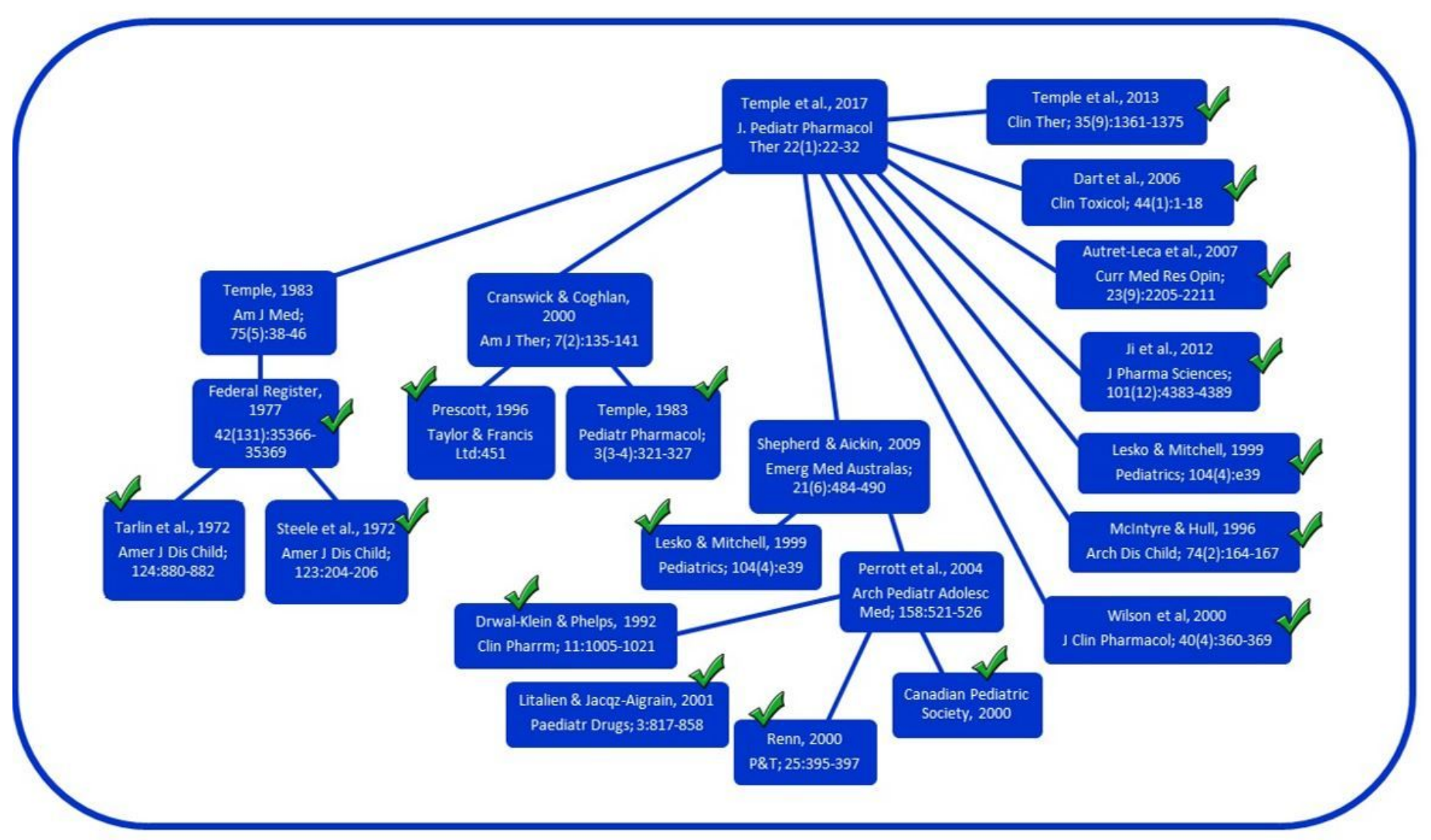

Figure 1

Flow diagram illustrating connections between articles claiming that paracetamol use is safe for infants or children when used as directed. In this example, the citations in a paper by Temple and colleagues in 2017 [25] are assessed. Articles describing new experiments designed to test safety of paracetamol or which contain claims of safety without citation are included in Table 2 and are indicated by a check mark. Articles shown in the diagram which do not describe experiments designed to test safety of paracetamol and which cite other articles as a source for claims of safety $[23,26,27,134]$ are not included in Table 2 and are not indicted by a check in the diagram. 


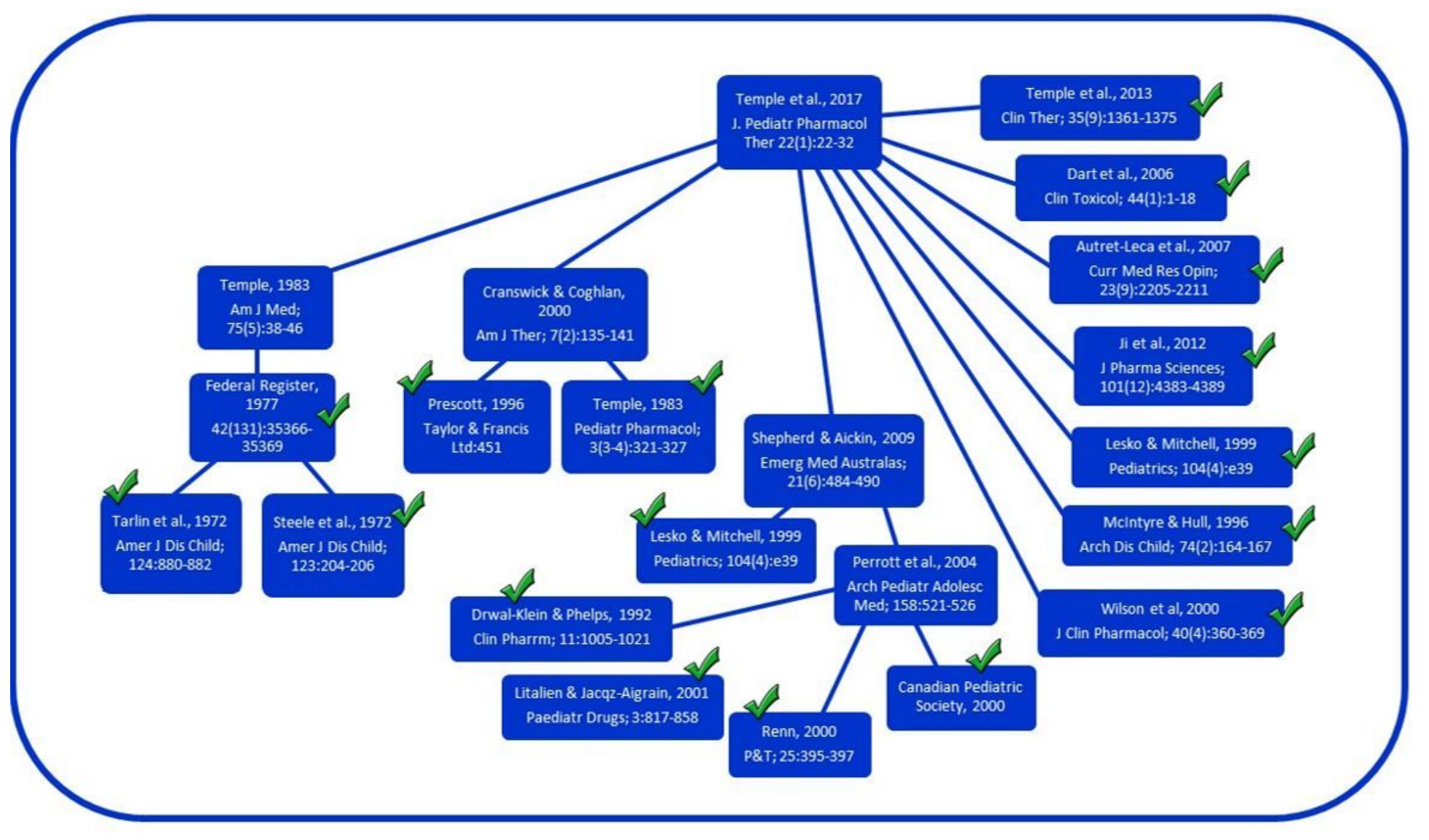

Figure 1

Flow diagram illustrating connections between articles claiming that paracetamol use is safe for infants or children when used as directed. In this example, the citations in a paper by Temple and colleagues in 2017 [25] are assessed. Articles describing new experiments designed to test safety of paracetamol or which contain claims of safety without citation are included in Table 2 and are indicated by a check mark. Articles shown in the diagram which do not describe experiments designed to test safety of paracetamol and which cite other articles as a source for claims of safety $[23,26,27,134]$ are not included in Table 2 and are not indicted by a check in the diagram. 


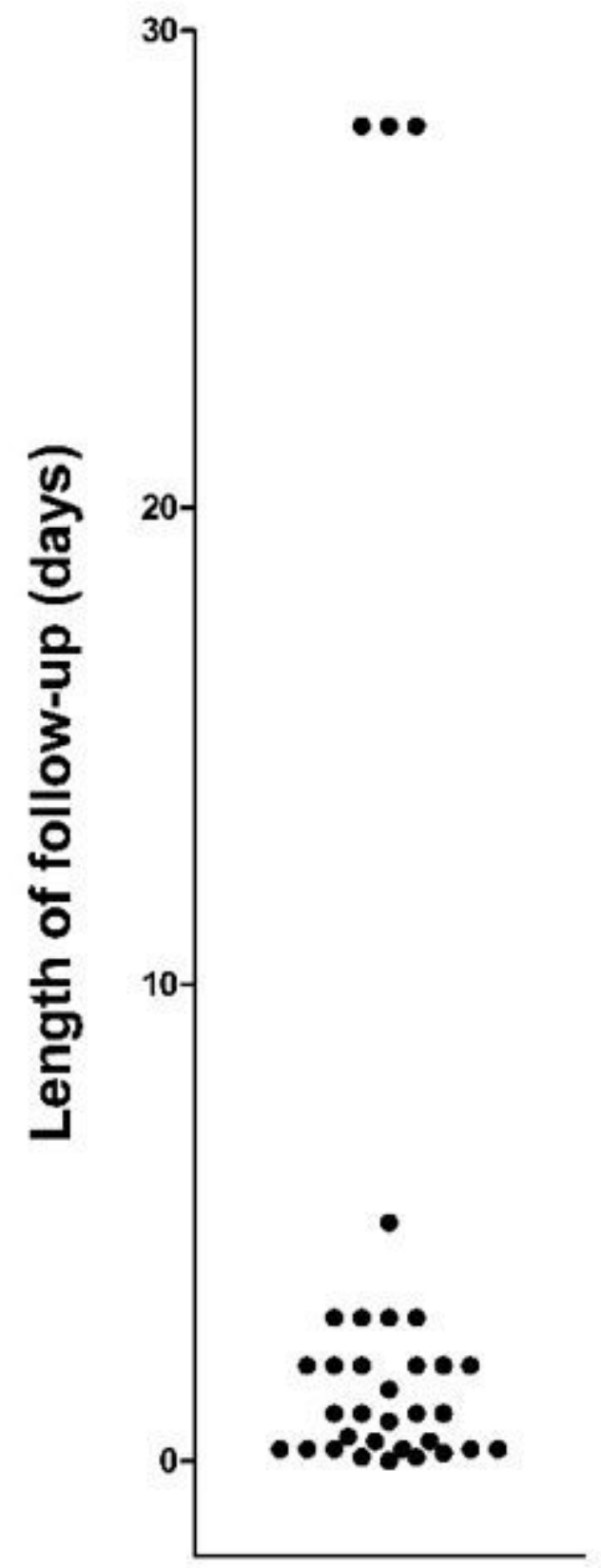

Figure 2

Maximum follow-up times for 34 of the 36 studies describing experiments designed to test the safety of acetaminophen in infants or children. One study [24] monitoring readmission for surgery for one year is omitted from the graph. Another study [66] observing patients during their inpatient visit did not specify duration of monitoring, and therefore could not be included in the graph. The three studies monitoring outcomes for 4 weeks (shown on the graph) did not monitor neuropsychiatric function. 


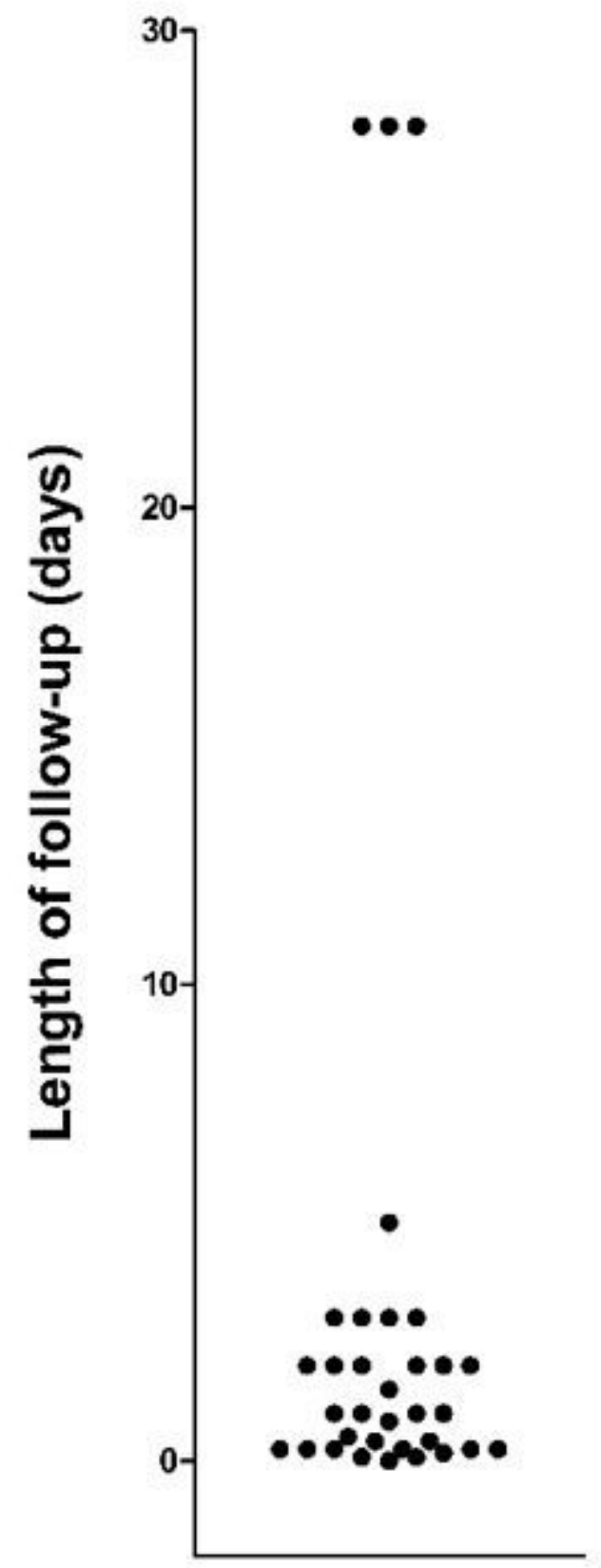

Figure 2

Maximum follow-up times for 34 of the 36 studies describing experiments designed to test the safety of acetaminophen in infants or children. One study [24] monitoring readmission for surgery for one year is omitted from the graph. Another study [66] observing patients during their inpatient visit did not specify duration of monitoring, and therefore could not be included in the graph. The three studies monitoring outcomes for 4 weeks (shown on the graph) did not monitor neuropsychiatric function.

\section{Supplementary Files}


This is a list of supplementary files associated with this preprint. Click to download.

- GB.JPG

- GB.JPG 